\title{
Cadeia de custódia da prova e investigações internas empresariais: possibilidades, exigibilidade e consequências processuais penais de sua violação
}

\author{
Chain of custody and corporate internal \\ investigations: possibilities, enforceability and \\ procedural consequences of its violation
}

\author{
Túlio Felippe Xavier Januário ${ }^{1}$ \\ Universidade de Coimbra, Portugal \\ tuliofxj@gmail.com \\ http://lattes.cnpq.br/1894712298793127 \\ http://orcid.org/0000-0003-0400-1273
}

\begin{abstract}
Resumo: Pretende-se com o presente trabalho, analisar as seguintes questões: seria possível e exigível a observância da cadeia de custódia dos elementos de informação advindos de investigações internas empresariais? Quais seriam as eventuais implicações de sua violação, caso se pretenda apresentar estes elementos em um posterior processo penal? Para responder a essas perguntas, realizaremos, inicialmente, um breve estudo a respeito das origens, formalidades e finalidades das investigações internas, que se encontram intimamente relacionadas aos mecanismos de autorregulação regulada e, em especial, aos programas de compliance. Uma vez se tratando, porém, de diligências promovidas em ambiente privado, sem contraditório judicial e com parcas regula-
\end{abstract}

1 Doutorando e Mestre em Direito pela Universidade de Coimbra, com período de investigação financiado pelo programa "ERASMUS+" na Georg-August-Universität Göttingen. Especialista em Direito Penal Econômico e Teoria do Delito pela Universidad de Castilla-La Mancha. Pós-graduado em Direito Penal - Parte Geral pelo IBCCRIM / IDPEE - Coimbra. Graduado em Direito pela Universidade Estadual Paulista - UNESP. Bolsista de Doutorado da Fundação para a Ciência e a Tecnologia - FCT. 
mentações estatais, levanta-se, dentre outros questionamentos, o de como assegurar a rastreabilidade das fontes de prova nestes ambientes. Assim, após um estudo sobre o instituto da cadeia de custódia e de seus fundamentos, buscaremos analisar, a partir de uma metodologia dedutiva, de que forma pode ser assegurada a autenticidade e a integralidade dos documentos advindos das investigações internas e quais seriam os possíveis reflexos processuais penais da "quebra" da cadeia de custódia destas provas.

Palavras-chave: Processo penal das pessoas jurídicas; compliance; investigações internas; provas; cadeia de custódia.

ABSTRACT: The aim of the present essay is to analyze the following questions: Is it possible and enforceable the observance of the chain of custody of the evidence from corporate internal investigations? Which are the eventual implications of its violation when it is intended to present these elements in a future criminal procedure? To answer these questions, we will initially carry out a brief study on the origins, formalities and purposes of these procedures, which are closely related to the mechanisms of enforced self-regulation, particularly to the compliance programs. However, since they are diligences promoted in a private scope, without due adversarial procedures and with limited state regulations, it is questioned how to ensure the traceability of the evidence sources in these environments. Therefore, after a study on the chain of custody and its fundamentals, we will seek to analyze, from a deductive methodology, how the authenticity and completeness of the documents arising from internal investigations can be assured and what are the possible consequences in criminal proceedings, of the "breaking" of these chain of evidence.

KEYWORDs: Criminal procedure against legal persons; compliance; internal investigations; evidence; chain of custody.

SUMÁRıO: Introdução. 1. Das investigações internas empresariais. 2. Cadeia de custódia da prova: conceito, fundamentos e relevância processual penal. 3. Rastreabilidade das fontes de prova nas investigações internas: possibilidades, fundamentos e eventuais implicações de sua violação. Conclusão. Referências. 


\section{INTRODUÇÃO}

A observada ascensão das corporações a um patamar de protagonis$\mathrm{mo}^{2}$ em diversos setores ${ }^{3}$, viabilizada pela globalização econômica e comunicacional ${ }^{4}$ e pela consequente aproximação dos mercados, trouxe consigo uma maior preocupação para com a chamada "criminalidade corporativa" ,

2 Para uma análise histórica do processo de ascensão das corporações a este patamar de protagonismo, destacando, inclusive, o potencial de impacto social das mesmas quando não apenas baseadas, mas também voltadas à produção de evidências científicas, conferir em: SAAD-DINIZ, Eduardo. Ética negocial e compliance: entre a educação executiva e a interpretação judicial. São Paulo: Thomson Reuters Brasil, 2019. p. 23-35.

3 Laura Zuñiga Rodríguez destaca, inclusive, o protagonismo das empresas no "mundo do crime", uma vez que a estruturação altamente complexa, especializada e hierarquizada destas sociedades, somada ao fato de que elas concentram uma grande parcela do capital mundial, transformam-nas em uma relevantíssima fonte de riscos. Conferir com detalhes em: ZUÑIGA RODRÍGUEZ, Laura. Bases para un modelo de imputación de responsabilidad penal a las personas jurídicas. Navarra: Aranzadi, 2000. p. 80-81.

4 Conforme explica Silva Sánchez, a globalização económica, caracterizada pela busca da eliminação de restrições às transações e pela consequente ampliação dos mercados, conjuntamente com sua vertente "comunicacional", viabilizada pelas inovações técnicas e que possibilita um barateamento das operações, têm como um dos impactos no direito penal e na política criminal, o alvorecer de novas conformações delitivas, em especial, de uma criminalidade que pode ser considerada "organizada" e perpetrada por sujeitos poderosos. Neste sentido: SILVA SÁNCHEZ, Jesús-María. La expansión del derecho penal: aspectos de la Política criminal en las sociedades postindustriales. 3. ed. ampl. Madrid: Edisofer S. L., 2011. p. 88-91.

5 No mesmo sentido que Schünemann, podemos considerar como "criminalidade corporativa", ou "criminalidade empresarial”, a que engloba os delitos econômicos cometidos por meio de uma atuação para uma empresa, através dos quais sejam lesados bens jurídicos externos, incluídos os interesses dos próprios colaboradores da empresa. Cumpre destacar, porém, que o autor exclui do conceito, os delitos cometidos contra a própria empresa ou contra seus membros, ainda que no cerne empresarial. Cfr em: SCHÜNEMANN, Bernd. Cuestiones básicas de dogmática jurídico-penal y de política criminal acerca de la criminalidad de empresa. Anuario de derecho penal y ciencias penales, Madrid, v. 41, n. 2, p. 529-558, mai./ago. 1988, p. 529-531. Conforme observaremos posteriormente, não obstante o conceito aqui adotado, os interesses do presente trabalho vão além das hipóteses apontadas, sendo as investigações internas de central importância também no escopo dos crimes cometidos contra a empresa e através da empresa, contra seus trabalhadores. 
cuja magnitude dos seus potenciais danos ${ }^{6}$ tem se mostrado cada vez mais evidente.

Contudo, constata-se que o Estado, por si só, encontra inegáveis dificuldades na regulação e fiscalização das atividades empresariais e mais ainda, na prevenção, investigação e persecução dos ilícitos cometidos no setor, o que se justifica, em linhas gerais, pela organização extremamente complexa que estas entidades assumem ${ }^{7}$, pela sua atuação em âmbitos muito técnicos e especializados e pela própria permeação do ambiente empresarial por uma cultura de máxima potencialização dos lucros, ainda que, em alguns casos, às custas da ética e da legalidade.

Neste contexto, os programas de compliance vão sendo desenvolvi-

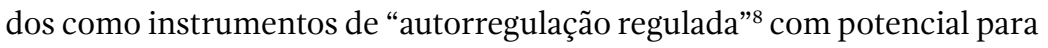
remediar as dificuldades supracitadas. Dentre os mecanismos dos quais normalmente dispõem, especialmente no que toca ao seu viés reativo, encontram-se os procedimentos de investigação interna, os quais, mediante a condução de diligências como a coleta de documentos físicos e digitais e a realização de entrevistas e de exames técnicos, visam, dentre outras finalidades, a apuração de fatos potencialmente ilícitos ou antiéticos que cheguem ao seu conhecimento.

6 Conforme bem aponta Eduardo Saad-Diniz, "o comportamento negocial das lideranças corporativas levou economias mais ou menos sólidas ao colapso, mobilizou guerras e é o pivô do aquecimento global". Ademais, "desintegra regimes políticos democráticos e é indiferente aos efeitos deletérios da atividade empresarial na realização da justiça social” (SAAD-DINIZ, Eduardo. Op. Cit., p. 16).

7 Em sentido próximo: PIETH, Mark; IVORY, Radha. Emergence and convergence: corporate criminal liability principles in overview. In: PIETH, Mark; IVORY, Radha (ed.). Corporate criminal liability: emergence, convergence and risk. Rotterdam: Springer Netherlands, 2011. p. 3-62, p. 4-5; GARCIA CAVERO, Percy. Criminal compliance. Lima: Palestra Editores, 2014. p. 2014. p. 13-15.

8 O conceito de "autorregulação regulada" será melhor analisado oportunamente. Sumariamente, no mesmo sentido que Susana Aires de Sousa, podemos destacar que as empresas acabam por assumir perante às autoridades públicas, o compromisso de se organizarem e autorregularem, devendo não apenas atuar de maneira conforme ao direito, mas ainda se "autofiscalizarem" para a prevenção e repressão de ilícitos. Neste sentido: SOUSA, Susana Aires de. Questões fundamentais de direito penal da empresa. Coimbra: Almedina, 2019. p. 123-124. 
Uma vez, porém, que se tratam de medidas investigativas promovidas por particulares e cujos fatos podem estar relacionados a uma investigação oficial ou a um processo criminal em curso ou iminente, inúmeros são os questionamentos levantados não apenas com relação aos possíveis excessos cometidos pelas empresas em desfavor dos direitos e garantias de seus colaboradores e demais envolvidos, mas também quanto à idoneidade das informações colhidas e à possível admissão e posterior valoração delas em um processo penal ${ }^{9}-^{10}$.

O objetivo do presente trabalho se insere, assim, no específico escopo da cadeia de custódia da prova e sua eventual aplicação no caso das investigações internas corporativas. Para tanto, após um breve - porém necessário - estudo do conceito, das finalidades e dos procedimentos

9 A despeito das peculiaridades inerentes à seara de criminalidade na qual se insere o presente trabalho, partimos do pressuposto inafastável de que a eficiência e a funcionalidade do processo penal somente podem ser buscadas no "interior da sua tradicional função de garantia". Impõe-se, pois, que as finalidades de política-criminal que demandem uma maior funcionalidade do processo, se movam "dentro das balizas postas pelo vector garantia..." (FERNANDES, Fernando Andrade. O processo penal como instrumento de política criminal. Coimbra: Almedina, 2001. p. 54; 67).

10 Não desconhecemos a possibilidade fática de que estes elementos sejam utilizados também em procedimentos sancionatórios de cariz não penal, hipóteses essas que, ao menos no ordenamento jurídico brasileiro, talvez sejam de ainda maior incidência, diante da limitação da responsabilidade penal das pessoas jurídicas aos crimes ambientais. Ainda que tenhamos sustentado em outra oportunidade, a imperiosidade da observação, também no processo administrativo sancionador brasileiro, de algumas garantias (tais como a do nemo tenetur se detegere), a ausência, no Brasil, de um sistema contraordenacional bem estruturado, nos moldes do sistema português, certamente é um fator complicador para a compreensão das eventuais implicações neste âmbito - se existentes - dos vícios na rastreabilidade probatória. Cfr.: CANESTRARO, Anna Carolina; KASSADA, Daiane Ayumi; JANUÁRIO, Túlio Felippe Xavier. Nemo tenetur se detegere e programas de compliance: o direito de não produzir prova contra si próprio em face da Lei n. 13.303/16. In: SAAD-DINIZ, Eduardo et. al. (orgs.). Direito penal econômico nas ciências criminais. Belo Horizonte: Editora Vorto, 2019. p. 311-342. p. 332-336. Aliás, conforme aponta Claudia Barrilari, a deficiência na regulação do direito administrativo sancionador tende a ter como consequência, justamente, uma flexibilização de garantias e princípios tradicionalmente assegurados em matéria penal. Neste sentido, cfr.: BARRILARI, Claudia Cristina. Crime empresarial, autorregulação e compliance. São Paulo: Thomson Reuters Brasil, 2018. p. 46. De todo modo, no presente estudo, centrar-nos-emos nas reverberações no plano processual penal. 
realizados nas investigações internas, bem como de sua relevância no âmbito dos programas de compliance, buscaremos responder às seguintes perguntas: é possível, exigível e de que forma ocorreria a observância da rastreabilidade das fontes de prova, quando elas forem provenientes de investigações internas? Em caso de resposta positiva, quais seriam as implicações processuais penais da violação desta cadeia?

Para tanto, faremos uso de uma metodologia dedutiva, tendo como premissas gerais a legislação, doutrina e jurisprudência em matéria de cadeia de custódia da prova, aplicando-as ao caso específico das investigações internas empresariais. Ao fim do trabalho, buscaremos demonstrar que apesar da imperiosidade da observância da cadeia de custódia dos elementos de informação advindos de investigações internas, eventuais vícios não impedirão a admissibilidade dos mesmos em processo penal, desde que a valoração deles seja feita em benefício exclusivo da defesa do Acusado, sem prejuízo de um exame judicial de fiabilidade das informações por eles apresentadas.

\section{Das inVestigações INTERnAs EMPRESARIAis}

Conforme fora mencionado no tópico introdutório, as investigações internas se inserem, via de regra, no âmbito dos chamados "programas de compliance", instituto que muito embora tenha recebido recente grande atenção doutrinária, tem suas origens na primeira metade do Século XX, no específico escopo da proteção da concorrência e do mercado de valores norte-americano. Segundo Adán Nieto Martín, em meados dos anos 40, o Departamento de Justiça dos Estados Unidos desarticulou um cartel de fabricantes de componentes elétricos, passando a exigir das empresas do setor, a implementação dos programas supracitados para a prevenção de condutas anticoncorrenciais ${ }^{11}{ }^{12}$.

11 NIETO MARTÍN, Adán. O cumprimento normativo. In: NIETO MARTíN, Adán; SAAD-DINIZ, Eduardo; GOMES, Rafael Mendes (coord.). Manual de cumprimento normativo e responsabilidade penal das pessoas jurídicas. 1. ed. Florianópolis: Tirant lo Blanch, 2018. p. 29-60. p. 31.

12 Importante ressalva é feita, porém, por Eduardo Saad-Diniz, que salienta que as manifestações exordiais de compliance eram tímidas, senão meramente 
No âmbito do mercado de valores, porém, os programas de compliance remontam a um período ainda anterior, sendo que já nos anos 30 , a Securities and Exchange Comission - SEC passou a exigir o estabelecimento de controles internos (self-policing) para fins de evitar o abuso de informações privilegiadas. Com isso, explica o autor que nos anos 50, grande parte das corretoras de valores e demais intermediários financeiros já adotavam estes mecanismos, os quais ganharam ainda maior destaque com os escândalos de Wall Street nos anos 80, quando passaram a ser exigidos pela $S E C$, de maneira generalizada, de todas as corretoras de valores mobiliários que operassem na bolsa ${ }^{13}{ }^{14}$.

Contudo, foi no contexto dos graves escândalos financeiros da virada do século - tais como os observados nos casos Enron, WorldCome Parmalat $^{15}$-, e posteriormente com a crise dos derivativos de 2008 , que a eficácia da "autorregulação" dos atores econômico-financeiros, de maneira livre de qualquer intervenção ou regulamentação estatal, passou a ser questionada, especialmente quanto à sua idoneidade para a prevenção de ilícitos ${ }^{16}$. Ganha fôlego, então, a ideia de uma "autorregulação regulada”, como contrapartida às políticas neoliberais e de desregulação que deram espaço às condutas ilícitas supracitadas, as quais a supervisão estatal não fora apta a evitar ${ }^{17}$.

profiláticas, distando muito da hodierna configuração destes programas. Cfr.: SAAD-DINIZ, Eduardo. Op. cit., p. 125.

13 Conforme explica Howard M. Friedman, a Insider Trading and Securities Fraud Enforcement Act of 1988 tornou mandatórios os programas de compliance para empresas de corretagem e consultoria de investimento, as quais poderiam ser responsabilizadas como controlling persons. Conferir com detalhes em: FRIEDMAN, Howard M. The Insider Trading and Securities Fraud Enforcement Act of 1988. North Carolina Law Review, v. 68, n. 3, p. 465-494, 1990. p. 477. Disponível em: <https://scholarship.law.unc.edu/nclr/vol68/ iss3/2/>. Acesso em 18 de junho de 2020. NIETO MARTÍN, Adán. Op. Cit., p. 32.

15 Neste sentido, destacando ainda, a relevância destes casos para a aprovação da Sarbanes Oxley Act - SOX: NIETO MARTÍN, Adán. Op. Cit., p. 32.

16 SARCEDO, Leandro. Compliance e responsabilidade penal da pessoa jurídica: construção de um novo modelo de imputação baseado na culpabilidade corporativa. São Paulo: LiberArs, 2016. p. 24.

17 RODRIGUES, Anabela Miranda. Direito penal económico: uma política criminal na era compliance. Coimbra: Almedina, 2019. p. 45. 
Com as constatadas dificuldades encontradas pelo Estado para a realização de suas atividades de regulação, prevenção, investigação e repressão de delitos empresariais ${ }^{18}$, este passa a incorporar os entes particulares na realização dessas suas funções, as quais são para eles delegadas, mas de maneira vinculada e subordinada aos fins e interesses estatais $^{19}$. Desta feita, nesta enforced self-regulation, o ente privado é demandado a definir seus próprios estandartes, os quais serão ratificados pelo Estado, quando consonantes à legislação pública, e cujas violações poderão ser punidas ${ }^{20}$.

É neste apontado contexto de efervescência dos ideais autorregulatórios, somados à cada vez maior necessidade de tutela dos direitos dos acionistas $^{21}$, que os programas de compliance, em sua hodierna configuração, se inserem. Eles podem ser conceituados como uma ferramenta de autofiscalização e autorregulação empresarial, inserida na conjuntura da governança corporativa, que tem como propósitos imediatos a promoção de uma cultura de ética e de cumprimento normativo nas atividades empresariais, bem como a prevenção, investigação e repressão de práticas ilícitas neste ambiente. Mediatamente, busca-se a manutenção ou recuperação da boa-reputação da pessoa jurídica, a continuidade dos negócios com a potencialização de seus lucros e, principalmente, o resguardo da corporação, de seus colaboradores e de seus órgãos de representação,

18 Dificuldades estas que já eram apontadas por Braithwaite, em 1982, em: BRAITHWAITE, John. Enforced self-regulation: a new strategy for corporate crime control. Michigan Law Review, v. 80, n. 7, p. 1466-1507, jun./1982.

COCA VILA, Ivó. ¿Programas de cumplimiento como forma de autorregulación regulada? In: SILVA SÁNCHEZ, Jesús-María (dir.); MONTANER FERNÁNDEZ, Raquel (coord.). Criminalidad de empresa y compliance: prevención y reacciones corporativas. Barcelona: Atelier, 2013. p. 43-76. p. 51.

20 AYRES, Ian; BRAITHWAITE, John. Responsive regulation: transcending the deregulation debate. Oxford: Oxford University Press, 1992. p. 101; 107.

Conforme explica Sarcedo, os acionistas hodiernos investem seus recursos em atividades econômicas sobre as quais não têm controle administrativo e operacional direto e localizado. Cfr.: SARCEDO, Leandro. Op. Cit., p. 41-42. Trata-se de uma nova conformação da categoria apontada por Bauman como de "proprietários ausentes", cujos únicos limites para seus investimentos são os impostos administrativamente sobre o livre movimento do capital. Neste sentido: BAUMAN, Zygmunt. Globalização: as consequências humanas. Rio de Janeiro: Zahar, 1999. p. 12 e ss. 
de eventuais responsabilizações nas mais variadas esferas, bem como de prejuízos financeiros e reputacionais ${ }^{22}$.

Podemos considerar que estes programas atuam em quatro "frentes" no âmbito corporativo, sendo elas: a I) frente regulatória - estabelecimento de normas internas, padrões éticos e de conduta, competências, procedimentos e demais instrumentos necessários para o bom andamento das atividades; a II) frente preventiva - visando obstar ocorrências que podem se mostrar prejudiciais à empresa, inclusive em termos de posteriores responsabilizações; III) a frente investigativa, referente às ocasiões em que a pessoa jurídica se vê na posição de apurar ocorrências potencialmente antinormativas que cheguem ao seu conhecimento; IV) e a frente reativa, composta pelos procedimentos "post-factum" do compliance, tais como as sanções internas e os mecanismos de revisão e melhoramento contínuo do programa ${ }^{23}$.

Uma análise pormenorizada e exaustiva de cada um dos mecanismos que compõem um programa de compliance restaria prejudicada, não apenas pelo fato de que eles dependem das particularidades de cada empresa e de seu ramo de atuação, bem como dos mais variados riscos penais aos quais estas estão submetidas ${ }^{24}$, mas também extrapolaria os limites temáticos do presente trabalho. A título exemplificativo, remetemos à classificação proposta por Engelhart, que divide as etapas da elaboração destes programas em três colunas, quais sejam: I) a da formulação, caracterizada pelo trinômio detectar - definir - estruturar, que engloba os procedimentos de identificação e análise de riscos, a aprovação de um código de ética e de outras normativas internas, a implantação de canais de denúncia e orientação e a definição das respectivas competências no âmbito do programa; II) a da implementação, definida pelo trinômio

22 JANUÁRIO, Túlio Felippe Xavier. Criminal compliance e corrupção desportiva: um estudo com base nos ordenamentos jurídicos do Brasil e de Portugal. Rio de Janeiro: Lumen Juris, 2019. p. 85-86.

Ibidem, p. 86-87.

24 Neste sentido: SIEBER, Ulrich. Compliance-Programme im Unternehmensstrafrecht: ein neues Konzept zur Kontrolle von Wirtschaftskriminalität. In: SIEBER, Ulrich; DANNECKER, Gerhard; KINDHÄUSER, Urs; VOGEL, Joachim; WALTER, Tonio (Hrsg.). Strafrecht und Wirtschaftsstrafrecht - Dogmatik, Rechtsvergleich, Rechtstatsachen: Festschrift für Klaus Tiedemann zum 70. Geburtstag. Köln: Carl Heymanns Verlag, 2008. p. 449-484. p. 458. 
comunicar - promover - organizar, e composta pelas fases de divulgação do programa e treinamento dos colaboradores e de promoção cotidiana da cultura de compliance; e por fim, III) a consolidação e aperfeiçoamento, marcada pelo trinômio reagir - sancionar - aperfeiçoar, e que diz respeito aos procedimentos de investigação interna e sancionamento, bem como aos mecanismos de avaliação e melhoramento contínuo do programa ${ }^{25}$.

Como podemos observar, o objeto do presente trabalho se encontra na "terceira coluna", mais especificamente no que toca à "frente investigatória” dos programas de compliance ${ }^{26}$. É fato que, por mais desenvolvidos e bem estruturados que estes mecanismos venham a ser em determinada empresa, eles não serão capazes de eliminar completamente os riscos de práticas ilícitas e antiéticas, sendo fundamental, portanto, que a estrutura de compliance esteja dotada de mecanismos que permitam a apuração dos fatos e de suas respectivas autorias.

As investigações internas podem ser conceituadas, assim, como o conjunto de diligências empregadas por uma determinada pessoa jurídica, com ou sem o auxílio de colaboradores externos contratados para tanto, as quais têm como uma de suas finalidades a apuração dos fatos que cheguem ao seu conhecimento e que apresentem indícios de violações legais, éticas e/ou de suas normativas internas. Cumpre destacar, porém, que estes procedimentos não se confundem com as atividades cotidianas de supervisão e tampouco com os procedimentos de due diligence, pois ao contrário destas, eles apresentam um inegável caráter reativo e não cotidiano ${ }^{27}$.

25 Detalhadamente em: ENGELHART, Marc. Sanktionierung von Unternehmen und Compliance: eine rechtsvergleichende Analyse des Straf- und Ordnungswidrigkeitenrechts in Deutschland und den USA. 2. ergänzte und erweiterte Auflage. Berlin: Dunker \& Humblot, 2012. p. 711-719.

26 Como explica Lenze, as investigações internas se encontram no viés repressivo dos programas de compliance, os quais, para se mostrarem efetivos, devem conter não apenas mecanismos preventivos, mas também de detecção de irregularidades e posterior sancionamento. Conferir com detalhes em: LENZE, Sebastian. Compliance, Internal Investigations und Beschuldigtenrechte: Mitarbeiterfragungen im Rahmen unternehmensinterner Ermittlungen und die strafprozessuale Verwertbarkeit selbstbelastender Aussagen unter besonderer Berücksichtigung der Korruptionsfälle Siemens und MAN. Frankfurt am Main: Peter Lang GmbH, 2014. p. 76.

27 CANESTRARO, Anna Carolina; JANUÁRIO, Túlio Felippe X. Investigação defensiva corporativa: um estudo do Provimento 188/2018 e de sua eventual 
Conforme explica Scharnberg, muito embora as diligências individualmente consideradas sejam praticadas, a princípio, sem a participação das autoridades públicas, elas estão, via de regra, conectadas com investigações estatais ao menos iminentes, servindo, assim, para a compilação de informações que viabilizarão e fundamentarão as posteriores decisões a serem tomadas pela pessoa jurídica, em face dos fatos ${ }^{28}$.

Cumpre destacar que até pouquíssimo tempo atrás, estes instrumentos eram conduzidos sob o paradigma puro da autorregulação, no sentido de que, ao menos em matéria penal e processual penal, não havia regulamentações quanto aos procedimentos concretos a serem adotados pela empresa, salvo eventuais normativas em matéria laboral e societária ${ }^{29}$. Atualmente, porém, já é possível observar alguns esforços no sentido de viabilizar um maior controle sobre as concretas diligências conduzidas nesta seara. Estes empenhos ocorrem, por um lado, mediante a tentativa de delimitação - doutrinária ${ }^{30}$ e legislativa ${ }^{31}$ - do que pode ser

aplicação para as investigações internas de pessoas jurídicas. Revista Brasileira de Direito Processual Penal, Porto Alegre, v. 6, n. 1, p. 283-328, jan./ abr. 2020. p. 294.

28 SCHARNBERG, Josephine. Illegale internal Investigations: strafrechtliche Grenzen unternehmensinterner Ermittlungen. Frankfurt am Main: Peter Lang GmbH, 2015. p. 27.

29 Sustentando que as normas que regulam as investigações internas são procedentes do direito do trabalho e do direito societário: NIETO MARTÍN, Adán. Investigações internas. In: NIETO MARTÍN, Adán; SAAD-DINIZ, Eduardo; GOMES, Rafael Mendes (coord.). Manual de cumprimento normativo e responsabilidade penal das pessoas jurídicas. 1. ed. Florianópolis: Tirant lo Blanch, 2018. p. 293-334. p. 295.

30 Ao nível doutrinário, destacam-se, por todos, as proposições de Adán Nieto Martín, em: NIETO MARTÍN, Adán. Compliance, criminologia e responsabilidade penal de pessoas jurídicas. In: NIETO MARTÍN, Adán; SAAD-DINIZ, Eduardo; GOMES, Rafael Mendes (coord.). Manual de cumprimento normativo e responsabilidade penal das pessoas jurídicas. 1. ed. Florianópolis: Tirant lo Blanch, 2018, p. 61-122. p. 93-103.

31 Ao nível legislativo, destacam-se as previsões do Art. 31, 5, do Código Penal Espanhol, que ao definir os níveis necessários para a consideração da "eficácia” dos modelos de organização e gestão, assim dispõe: "Artigo 31 bis [...] 5 . Los modelos de organización y gestión a que se refieren la condición $1 .^{\mathrm{a}} \mathrm{del}$ apartado 2 y el apartado anterior deberán cumplir los siguientes requisitos: 1 . $^{\circ}$ Identificarán las actividades en cuyo ámbito puedan ser cometidos los delitos que deben ser prevenidos. $2 .^{\circ}$ Establecerán los protocolos o procedimientos 
considerado um programa de compliance eficaz para fins de atenuação ou isenção de responsabilidade penal das pessoas coletivas. Por outro lado, também observamos reflexos indiretos nas investigações internas, da expressa regulamentação das chamadas “investigações defensivas" ${ }^{2}$, tal

que concreten el proceso de formación de la voluntad de la persona jurídica, de adopción de decisiones y de ejecución de las mismas con relación a aquéllos. 3. ${ }^{\circ}$ Dispondrán de modelos de gestión de los recursos financieros adecuados para impedir la comisión de los delitos que deben ser prevenidos. $4 .^{\circ}$ Impondrán la obligación de informar de posibles riesgos e incumplimientos al organismo encargado de vigilar el funcionamiento y observancia del modelo de prevención. 5. ${ }^{\circ}$ Establecerán un sistema disciplinario que sancione adecuadamente el incumplimiento de las medidas que establezca el modelo. 6. ${ }^{\circ}$ Realizarán una verificación periódica del modelo y de su eventual modificación cuando se pongan de manifiesto infracciones relevantes de sus disposiciones, o cuando se produzcan cambios en la organización, en la estructura de control o en la actividad desarrollada que los hagan necesarios" (ESPAÑA. Código Penal y legislación complementaria: edición actualizada a 4 de marzo de 2019. Disponível em: <www.boe.es/legislacion/codigos/>. Acesso em 9 de junho de 2020).

32 Nos termos do Art. $1^{\circ}$. do Provimento 188/2018, do Conselho Federal da Ordem dos Advogados do Brasil, podemos conceituar as investigações defensivas como "o complexo de atividades de natureza investigatória desenvolvido pelo advogado, com ou sem assistência de consultor técnico ou outros profissionais legalmente habilitados, em qualquer fase da persecução penal, procedimento ou grau de jurisdição, visando à obtenção de elementos de prova destinados à constituição de acervo probatório lícito, para a tutela de direitos de seu constituinte" (CONSELHO FEDERAL DA ORDEM DOS ADVOGADOS DO BRASIL. Provimento No 188/2018: Regulamenta o exercício da prerrogativa profissional do advogado de realização de diligências investigatórias para instrução em procedimentos administrativos e judiciais. Disponível em: <https://www.oab.org.br/leisnormas/legislacao/ provimentos/188-2018>. Acesso em 26 de dezembro de 2019). Conforme tivemos a oportunidade de sustentar em outra oportunidade, uma vez sendo as investigações internas uma das possíveis concretizações do direito de defesa da pessoa jurídica, através das quais ela busca elementos para a constituição de seu acervo probatório, podemos considera-las uma espécie do gênero "investigações defensivas". Neste sentido, com detalhes: CANESTRARO, Anna Carolina; JANUÁRIO, Túlio Felippe X., Investigação defensiva corporativa..., p. 301-320. No mesmo sentido: DIAS, Gabriel Bulhões Nóbrega. A advocacia criminal, a investigação defensiva e a luta pela paridade de armas. Revista Brasileira de Ciências Criminais, São Paulo, v. 26, n. 150, p. 145-187, dez./2018, p. 158. 
como ocorre nos ordenamentos jurídicos norte-americano ${ }^{33}$ e italiano $^{34}$, e que se encontra em fase de discussão no Brasil, através do Provimento 188/2018 do Conselho Federal da Ordem dos Advogados do Brasil ${ }^{35}$ e do Projeto de Novo Código de Processo Penal ${ }^{36}$.

33 Ao nível deontológico, a American Bar Association prevê nos Criminal Justice Standards for the Defense Function e Guidelines for the Appointment and Performance of Defense Counsel in Death Penalty Cases, o dever de investigação por parte dos advogados de defesa, dispondo ainda a respeito dos standards e boas-práticas a serem observadas pelo profissional na condução destas diligências. Conferir com detalhes em: AMERICAN BAR ASSOCIATION. Criminal Justice Standards for the Defense Function. Fourth Edition. 2017. Disponível em: <https://www.americanbar.org/groups/criminal_justice/ standards/DefenseFunctionFourthEdition/>. Acesso em 29 de dezembro de 2019; AMERICAN BAR ASSOCIATION. Guidelines for the Appointment and Performance of Defense Counsel in Death Penalty Cases. 2003. Disponível em: <https://www.americanbar.org/groups/committees/death_penalty_representation/resources/aba_guidelines>. Acesso em 29 de dezembro de 2019.

34 Com as modificações promovidas pela Lei 397/00, o Codice di Procedura Penale também passou a regular as atividades investigatórias promovidas pela defesa, dispondo sobre as formas e finalidades destes atos. Conferir com detalhes em: ITALIA. Legge 7 dicembre 2000, n. 397: Disposizioni in materia di indagini difensive. Gazzetta Ufficiale n. 2 del 03-01-2001. Disponível em: <https://www.altalex.com/documents/leggi/2009/01/27/disposizioni-in-materia-di-indagini-difensive>. Acesso em 29 de dezembro de 2019.

Vide nota 32.

36 Em sua versão mais recente: “Art. 13. É facultado ao investigado, por meio de seu advogado, de defensor público ou de outros mandatários com poderes expressos, tomar a iniciativa de identificar fontes de prova em favor de sua defesa, podendo inclusive entrevistar pessoas. $\$ 1^{\circ}$ As entrevistas realizadas na forma do caput deste artigo deverão ser precedidas de esclarecimentos sobre seus objetivos e do consentimento formal das pessoas ouvidas. $\S 2^{\circ} \mathrm{A}$ vítima não poderá ser interpelada para os fins de investigação defensiva, salvo se houver autorização do juiz das garantias, sempre resguardado seu consentimento. $\$ 3^{\circ} \mathrm{Na}$ hipótese do $\S 2^{\circ}$ deste artigo, o juiz das garantias poderá, se for o caso, fixar condições para a realização da entrevista. $\$ 4^{\circ}$ Os pedidos de entrevista deverão ser feitos com discrição e reservas necessárias, em dias úteis e com observância do horário comercial. $\$ 5^{\circ} \mathrm{O}$ material produzido poderá ser juntado aos autos do inquérito, a critério da autoridade policial. $\$ 6^{\circ}$ As pessoas mencionadas no caput deste artigo responderão civil, criminal e disciplinarmente pelos excessos cometidos" (CONGRESSO NACIONAL. PL 8045/2010: Código de Processo Penal. Disponível em: <https://www. camara.leg.br/proposicoesWeb/fichadetramitacao?idProposicao=490263>. Acesso em 28 de dezembro de 2019). 
Devemos salientar, inicialmente, que não há uma obrigação de investigar, mas sim, um ônus ${ }^{37}$. Com isso queremos dizer que, ressalvadas eventuais exceções pontuais, não há uma imposição legal neste sentido, mas caso a empresa em questão não o faça, coloca em cheque não apenas a idoneidade e eficácia do seu programa, mas também a futura obtenção de eventuais "benefícios" processuais penais.

Em outras palavras, no que toca à implementação de programas de compliance ou da promoção de investigações internas, um dos primeiros questionamentos que são levantados diz respeito ao porquê do alto investimento que é feito nestes mecanismos, quando a pessoa coletiva não é obrigada a adotá-los e, mais ainda, quando a partir deles podem ser apurados elementos que levem à própria responsabilização da empresa ou de seus administradores.

Segundo Engelhart, existem seis níveis progressivos de influência estatal sobre as pessoas jurídicas, em termos de implementação de programas de compliance: I) a autorregulação, marcada pela abstenção estatal, em que os incentivos para a adoção destes programas viriam tão somente das potenciais benesses mercadológicas ou da exigência dos mesmos, para a participação em determinados mercados; II) o apoio informal do Estado, mediante treinamentos e outros incentivos, os quais podem advir, inclusive, a nível supranacional, sendo de suma importância não apenas quando direcionados às companhias propriamente ditas, mas também aos próprios Estados, pressionando-os a promover os programas; III) a recompensação do compliance, através, por exemplo, da abstenção de persecução penal em face de companhias que tenham um programa eficaz, ou da consideração destes na fase de sentenciamento;

37 Neste sentido, sustentamos em: JANUÁRIO, Túlio Felippe Xavier. O sigilo profissional no âmbito das pessoas jurídicas: um estudo da particular posição dos in-house lawyers e dos advogados de compliance e de investigações internas. Revista Brasileira de Ciências Criminais, São Paulo, v. 27, n. 159, p. 297-339, set./2019. p. 315. Em sentido próximo, Montiel sustenta que eventual obrigação somente poderia ser considerada se analisada a partir das exigências de boa governança derivadas do compliance. Legalmente, porém, não há esta obrigação. Conferir com detalhes em: MONTIEL, Juan Pablo. Sentido y alcance de las investigaciones internas en la empresa. Revista de Derecho de la Pontificia Universidad Católica de Valparaíso, v. XL, p. 251-277, 2013. p. 262-265. 
IV) o sancionamento das falhas ou da falta de compliance, que pode se consubstanciar no agravamento de penas eventualmente impostas ou até mesmo na determinação judicial da adoção de determinadas medidas ou de um programa completo; V) a exclusão da responsabilidade em razão do compliance, que se mostra um dos maiores e mais justos incentivos e vem sendo progressivamente adotada no âmbito da responsabilidade penal das pessoas jurídicas; e VI) uma obrigação geral de implementar programas de compliance, que seria o nível mais forte de incentivo, ainda mais se acompanhado de mecanismos eficazes de enforcement (através de agências reguladoras, por exemplo) e também de sanções. Essas obrigações gerais ainda não existem, podendo indicar um desconforto legislativo em interferir na liberdade negocial das empresas ${ }^{38}$. Contudo, obrigações setoriais são comuns, especialmente em searas nas quais a necessidade regulatória é mais evidente, tais como na do branqueamento de capitais ${ }^{39}$.

Ora, nos termos da classificação supramencionada, ressalvadas eventuais exceções setoriais, nas quais determinadas companhias possam

38 Conforme sustentamos em outra oportunidade, a opção adotada pela generalidade dos legisladores, de ficarem silentes quanto a uma eventual obrigatoriedade de condução de investigações internas, tem consequências positivas e negativas, nestes termos: "Por um lado, uma expressa imposição legislativa neste sentido poderia eventualmente implicar em conflito para com o direito à não-autoincriminação da pessoa jurídica e de seus membros, para além de poder gerar a peculiar necessidade de condução destes procedimentos, mesmo quando a sociedade empresária já tiver elementos de informação suficientes para adotar a medida colaborativa que julgar conveniente. Por outro lado, essa ausência de imposições legais tem como uma de suas potenciais consequências, a inexistência de maiores parâmetros quanto aos possíveis procedimentos destas investigações e seus limites, o que pode potencializar os riscos de desproteção dos direitos dos investigados, bem como gerar insegurança para a própria pessoa jurídica, que não tem critérios seguros para ter certeza se as eventuais decisões tomadas com base nessas investigações internas serão validadas e valoradas judicialmente" (CANESTRARO, Anna Carolina. JANUÁRIO, Túlio Felippe Xavier. Dos níveis de exigibilidade dos procedimentos de investigação interna. In: INSTITUTO BRASILEIRO DE CIÊNCIAS CRIMINAIS. Anais do CPCRIM: IV Congresso de Pesquisas em Ciências Criminais, de 21 a 23 de outubro de 2020. São Paulo: IBCCRIM, 2020. p. 215-237. Disponível em: <https://www.ibccrim.org.br/publicacoes/pagina/3>. Acesso em 20 de março de 2021. p. 230).

39 ENGELHART, Marc. The Nature and Basic Problems of Compliance Regimes. Freiburg im Breisgau: Max-Planck-Institut für ausländisches und internationales Strafrecht, 2018. https://doi.org/10.30709/archis-2018-3. p. 21-30. 
ser legalmente obrigadas a promover investigações internas, a sua não promoção poderá implicar, de todo modo: na consideração da ineficácia do programa e em prejuízo da obtenção de recompensas processuais - nível III; no sancionamento da companhia - nível IV; ou na impossibilidade de exclusão de sua responsabilidade criminal, se for o caso - nível V.

Seja como for, a decisão sobre a promoção ou não de uma investigação interna recai, em regra, sobre os administradores da sociedade, podendo ser delegada à pessoa ou departamento responsável pelo compliance $^{40}$. Seu impulso inicial, consubstanciado na chegada ao seu conhecimento dos fatos potencialmente ilícitos ou contrários às normativas empresariais, pode decorrer de uma comunicação interna - tais como uma denúncia mediante o competente canal ou uma suspeita advinda das atividades cotidianas de supervisão e controle - ou externa - como a promoção atual ou iminente de uma investigação estatal ou processo penal, comunicada diretamente à empresa ou noticiada na mídia ${ }^{41}{ }^{42}$.

Ressalvadas as particularidades de cada pessoa jurídica e de seus respectivos setores de atuação, o procedimento das investigações internas tende a seguir um rito minimamente uniforme. Em um primeiro momento, é primordial a aprovação de um plano de investigação, o qual viabilizará a aferição prévia dos seus custos, tempo demandado e limites dos métodos empregados, os quais deverão ser aprovados pelo órgão responsável sob pena de ilegitimidade do procedimento ou da medida concretamente adotada ${ }^{43}$.

É nesta fase, aliás, que há a designação de um responsável interno pelo procedimento e é feita a opção pela contratação ou não, de profissionais externos. Essa escolha poderá levar em conta, muitas vezes, o interesse da pessoa jurídica em assegurar o sigilo das investigações,

40 NIETO MARTÍN, Adán. Investigações internas..., p. 300.

41 Neste sentido: CANESTRARO, Anna Carolina; JANUÁRIO, Túlio Felippe X. Investigação defensiva corporativa..., p. 298.

42 Adán Nieto Martín sustenta a necessidade de uma “investigação" preliminar à investigação interna, principalmente nos casos de denúncias advindas do canal, para a apuração da verossimilhança das acusações. Conferir com detalhes em: NIETO MARTÍN, Adán. Investigações internas..., p. 297-298.

43 NIETO MARTÍN, Adán. Investigações internas..., p. 302-303. 
especialmente quando elas forem vinculadas a uma investigação estatal ou a um processo penal.

Isso porque, conforme já analisamos em outra oportunidade ${ }^{44}$, é bastante controversa a extensão do sigilo profissional aos chamados in-house lawyers - ou advogados internos -, levantando o questionamento sobre se estes gozariam de prerrogativas como a work-product-protection e o attorney-client-privilege ${ }^{45}$. Inclusive, o Tribunal de Justiça da União Europeia, em ao menos duas oportunidades, fez uma leitura muito restritiva destes institutos aos advogados internos, nomeadamente nos casos AM \& S Europe v. Commission of the European Communities $^{46} \mathrm{e}$ Akzo Nobel Chemicals Ltd. and Akcros Chemicals Ltd. v. Commission of the European Communities ${ }^{47}$.

44 Conferir com detalhes em: JANUÁRIO, Túlio Felippe Xavier. O sigilo profissional..., p. 316 e ss.

45 Sobre essa questão, conferir detalhadamente em: VASCONCELLOS, Vinicius Gomes de. "The Right to Counsel and the Protection of Attorney-Client Privilege in Criminal Proceedings": direito de defesa técnica e relações cliente-advogado no processo penal contemporâneo. Revista Brasileira de Ciências Criminais, São Paulo, v. 29, n. 176, p. 257-272, fev./2021. p. 263-264.

46 O Tribunal considerou que os requisitos necessários para a proteção do sigilo de correspondência entre advogados e seus clientes são: (I) que a correspondência tivesse sido elaborada em razão e no interesse do direito de defesa do cliente; (II) e que fosse uma comunicação com um advogado independente, habilitado a exercer a profissão em algum dos Estados-membros e não vinculado ao cliente por relação laboral. Conferir com detalhes em: EUROPEAN COURT. Judgment of the Court of 18 May 1982: AM \& S Europe Limited v. Commission of the European Communities. Legal Privilege. Case 155/79. Disponível em: <https://eur-lex.europa.eu/legal-content/EN/TXT/?uri=CELEX\%3A61979CJ0155>. Acesso em 21 de junho de 2020.

47 No caso concreto, o Tribunal considerou que não haveria violação da igualdade de tratamento entre advogados externos e internos, uma vez que estes últimos, em razão de sua dependência econômica e laboral, ocupariam uma posição substancialmente diferente. Conferir com detalhes em: EUROPEAN COURT. Judgment of the Court of First Instance (First Chamber, extended composition) of 17 September 2007: Akzo Nobel Chemicals Ltd. and Akcros Chemicals Ltd. v. Commission of the European Communities. Competition. Administrative Procedure. Commission's powers of investigation. Documents seized in the course of an investigation. Legal professional privilege protecting communications between lawyers and their clients. Admissibility. Disponível em: <https://eur-lex.europa.eu/legal-content/EN/TXT/?uri=CELEX\%3A62003TJ0125>. Acesso em 21 de junho de 2020. 
Ainda que esses entendimentos tenham sido proferidos no âmbito concorrencial comunitário e que consideremos, ainda assim, bastante questionável a sua aplicação ao específico caso das atividades de compliance e investigações internas eventualmente executadas por advogados internos ${ }^{48}$, é fato que, diante da inegável controvérsia, pode ser feita a opção pela contratação de advogados externos, a fim de assegurar a confidencialidade das investigações ${ }^{49}$.

De todo modo, seja para os advogados internos ou para os externos, devem ser outorgados os respectivos e expressos poderes de mandato e firmados os competentes termos de confidencialidade dos envolvidos na investigação, com a finalidade de garantir a legitimidade, bem como de preservar o sigilo das informações coletadas, se for o caso ${ }^{50}$.

Feito isso, são iniciadas as atividades de investigação propriamente ditas, mediante a coleta de informações advindas de instrumentos de trabalho - tais como computadores e celulares corporativos -, condução de entrevistas, análise de documentos, gravações de áudio, vídeo e de arquivos digitais - dentre os quais, cadeias de e-mails, ficheiros da web e discos rígidos. Pode se fazer necessária também, a realização de perícias técnicas ${ }^{51}$.

48 Uma análise pormenorizada desta problemática ultrapassaria os limites temáticos do presente trabalho. Em linhas gerais, sustenta-se aqui ser inadequada uma diferenciação per se entre advogados internos e externos, para fins de aplicação do dever de sigilo profissional, do attorney-client-privilege e da work-product-protection, salvo nas hipóteses em que o concreto ordenamento jurídico expressamente assim disponha. Preenchido o pré-requisito da inscrição do profissional na respectiva Ordem, as comunicações e materiais de trabalho dos advogados de compliance e de investigações internas estarão tuteladas pelas garantias de confidencialidade quando consideradas, no caso concreto, frutos de uma I) representação técnica em juízo; ou II) consultoria ou assessoria estritamente jurídica, vinculadas ou não a um litígio atual ou futuro. Quando, pelo contrário, forem derivadas de III) intermediação ou gestão de interesses alheios sem caráter jurídico, ou de consultoria e assessoria de caráter meramente estratégico, financeiro, econômico, dentre outros, essas comunicações não estarão protegidas por estas prerrogativas. Conferir com detalhes em: JANUÁRIO, Túlio Felippe Xavier. O sigilo profissional..., p. 326 e ss. Neste sentido: GASCÓN INCHAUSTI, Fernando. Proceso penal y persona jurídica. Madrid: Marcial Pons, 2012. p. 144-145. NIETO MARTÍN, Adán. Investigações internas..., p. 302-304. ferir com detalhes em: NESTLER, Nina. Internal Investigations: Definition 
Finalizadas as diligências investigativas, é apresentado um relatório final ao órgão interno ou pessoa responsável, no qual constarão as conclusões da investigação ${ }^{52}$. A destinação destas informações será decidida de acordo com os concretos interesses da corporação ${ }^{53}$, sendo que, caso identificadas práticas ilícitas ou contrárias às normativas internas, elas poderão: I) dar ensejo a sanções internas, tais como advertências, suspensões e demissões; II) serem resguardadas para a preparação e fundamentação da defesa da pessoa jurídica em posterior procedimento sancionatório (inclusive criminal) em que venha a ser implicada, apresentando as provas que entender cabíveis; ou ainda, III) poderão ser compartilhadas com as autoridades estatais competentes, para a respectiva incorporação destes elementos nas investigações oficiais e a possível obtenção, por parte da empresa, de algum dos benefícios supramencionados ${ }^{54}{ }^{55}$.

und rechtstatsächliche Erkenntnisse zu interner Ermittlungen in Unternehmen. In: KNIERIM, Thomas C.; RÜBENSTAHL, Markus; TSAMBIKAKIS, Michael (Hrsg.). Internal Investigations: Ermittlungen im Unternehmen. 2. neu bearbeitete Auflage. Heidelberg: C.F. Müller, 2016.p. 3-22. p. 19-20. Conforme salienta Maria João Antunes, da existência de mecanismos internos de apuração não decorre um necessário dever de denúncia às autoridades, por parte da empresa, dos crimes que venha a tomar conhecimento. Conferir com detalhes em: ANTUNES, Maria João. Privatização das investigações e compliance criminal. Revista Portuguesa de Ciência Criminal, Coimbra, ano 28, n. 1, p. 119-128, jan./abr. 2018. p. 121.

54 Neste sentido: CANESTRARO, Anna Carolina; JANUÁRIO, Túlio Felippe X. Investigação defensiva corporativa..., p. 299. Sobre a específica relação entre os programas de compliance e os acordos de não persecução penal, conferir também: CANESTRARO, Anna Carolina; JANUÁRIO, Túlio Felippe Xavier. Acordo de não persecução penal como instrumento de promoção de programas de compliance?. Boletim IBCCRIM, ano 29, n. 344, p. 23-25, jul./2021.

55 No que toca à essa "colaboração" para com as autoridades públicas de enforcement, Baer explica que ela poderá ocorrer de acordo com três modelos: I) o sequencial, no qual o ente privado realiza todas as diligências necessárias para a apuração do fato e entrega ao ente público suas conclusões, para que este tome as providências que entender cabíveis; II) o cooperativo, no qual os entes público e privado conduzem as investigações de maneira conjunta, compartilhando livremente as informações que entenderem pertinentes; e o III) competitivo, no qual os investigadores públicos e privados são basicamente adversários, almejando descobrir as evidências relevantes antes que o outro o faça, para assim obter com elas as maiores vantagens. Cfr.: BAER, Miriam H. When the Corporation Investigates Itself. In: ARLEN, Jennifer 
É justamente desta última hipótese que decorrem alguns dos inúmeros questionamentos relacionados às investigações corporativas e seus possíveis aproveitamentos em processo penal. Primeiramente, porque neste espaço de verdadeira "privatização" das investigações ${ }^{56}$, não pode ser descartada a possibilidade de que empresas eticamente "questionáveis" conduzam essas diligências de maneira abusiva e desproporcional, violando direitos e garantias dos eventuais envolvidos, ou então, que haja uma tentativa de "direcionamento" 57 do resultado das investigações para afastar a responsabilidade da corporação e de ocupantes de cargos hierarquicamente superiores ${ }^{58}$, em desfavor de colaboradores subordinados ${ }^{59}$.

(ed.). Research Handbook on Corporate Crime and Financial Misdealing. Cheltenham, UK: Elgar, 2018. p. 308-333.. p. 323-324.

Conforme explica Maria João Antunes, essa "privatização" da investigação criminal no âmbito dos programas de compliance se consubstancia nas investigações internas, através das quais há uma colaboração empresarial com a apuração da existência de crimes, na determinação das respectivas autorias e responsabilidades e na recolha de provas. Conferir com detalhes em: ANTUNES, Maria João. Op. Cit., p. 121-122.

57 Conforme apontam Balcarce e Berruezo, no âmbito da criminalidade empresarial, há o risco de "deslizamento" do risco penal, ou risk shifting, que diz respeito à eventual tentativa dos administradores, de transferir suas respectivas responsabilidades criminais a ocupantes de cargos mais baixos ou até mesmo à pessoa coletiva. Conferir com detalhes em: BALCARCE, Fabián I.; BERRUEZO, Rafael. Criminal compliance y personas jurídicas. Buenos Aires: Editorial B de F, 2016. p. 163-164. Esta ideia de risk shifting fora desenvolvida e tratada em pormenor por Willian S. Laufer, em: LAUFER, William S. Corporate Liability, Risk Shifting, and the Paradox of Compliance. Vanderbilt Law Review, v. 52, n. 5, p. 1343-1420, out./1999. Disponível em: <https:// scholarship.law.vanderbilt.edu/vlr/vol52/iss5/9>. Acesso em 29 de junho de 2020. p. 1368 e ss. No mesmo sentido, conferir: NIETO MARTÍN, Adán. La responsabilidad penal de las personas jurídicas: un modelo legislativo. Madrid: Iustel, 2008. p. 208.

Essa preocupação também fora mencionada por Claudia Barrilari, que destaca a cautela que se deve ter na opção legislativa pelos modelos de responsabilidade penal das pessoas físicas e jurídicas, de modo a impedir que as práticas preventivas sejam direcionadas tão somente no sentido do encobrimento da responsabilidade individual daqueles que detenham o poder de comando na sociedade empresarial. Cfr.: BARRILARI, Claudia Cristina. Op. Cit., p. 204.

59 Conforme sustentamos mais detalhadamente em: CANESTRARO, Anna Carolina; JANUÁRIO, Túlio Felippe X., Investigação defensiva corporativa..., p. 301. 
Ademais, uma vez que no cerne destas investigações é coletado amplo acervo probatório, o qual, conforme salientamos, não necessariamente se limitará a tentar isentar a pessoa jurídica de uma sanção ou até mesmo evitar a instauração de um procedimento penal em face da mesma, mas também poderá apontar os responsáveis individuais pelos fatos investigados, a simples transferência dos resultados dessas investigações para as entidades estatais de persecução penal ou sua apresentação direta em juízo em conjunto com a defesa da corporação ${ }^{60}$, levanta grandes questionamentos sobre como compatibilizar esses procedimentos com as garantias processuais penais dos envolvidos, tais

${ }^{60}$ Para salientar a relevância desta discussão, destacamos a explicação feita por Arlen e Buell, que demonstram que no sistema jurídico norte-americano, as empresas não enfrentam restrições na investigação de seus empregados, mesmo quando dessas diligências se vislumbre a colaboração para com investigações oficiais do poder público no futuro. Inclusive, explicam os autores que, em caso de recusa do empregado, ele poderá ter seu contrato rescindido. Ademais, sequer o direito a um advogado seria assegurado ao empregado investigado. Não bastasse isso, os membros da Acusação poderiam fazer livre uso destas evidências em um posterior processo, ainda que tenha se configurado uma eventual coerção na sua obtenção. Cfr. com detalhes e citações em: ARLEN, Jennifer; BUELL, Samuel W.. The Law of Corporate Investigations and the Global Expansion of Corporate Criminal Enforcement. University of Southern California Law Review, v. 93, n. 4, p. 697-762, set./2020. Disponível em: <https://southerncalifornialawreview. com/2020/09/06/the-law-of-corporate-investigations-and-the-global-expansion-of-corporate-criminal-enforcement/>. Acesso em 21 de março de 2021. p. 719-720. 
como o direito à não autoincriminação, ao contraditório e à presunção de inocência' ${ }^{61}{ }^{62}$.

O objetivo do presente trabalho se encontra, porém, em um terceiro ponto controvertido, qual seja, o de como garantir a fidedignidade

61 Conforme explica Maria João Antunes, no âmbito dos processos penais em que sejam arguidas pessoas coletivas, apresenta especial relevo o questionamento sobre a possibilidade de valoração dos elementos coletados pela empresa nas suas investigações internas, sendo que aquela poderá ter interesse em apresenta-los em juízo, no exercício do seu direito de defesa, ainda que sua produção tenha se dado fora do processo penal, no cerne de uma entidade privada. Conferir em: ANTUNES, Maria João. Processo penal e pessoa coletiva arguida. Coimbra: Almedina, 2020. p. 68. Segundo Ana Pais, uma vez que "as investigações internas não estão amarradas às peias que se impõem à investigação criminal", há um risco de que elas sejam conduzidas ao arrepio das garantias de defesa e dos mais basilares princípios do processo penal, tal como o nemo tenetur se ipsum accusare. Neste sentido: PAIS, Ana. Os programas de compliance e o risco de privatização do processo penal. Em especial, a problemática da "prova emprestada" e o princípio nemo tenetur se ipsum accusare. In: COSTA, José de Faria et. al. (coord.). Estudos em homenagem ao Prof. Doutor Manuel da Costa Andrade: Volume II: Direito Penal: Direito Processual Penal. Coimbra: Instituto Jurídico da Faculdade de Direito da Universidade de Coimbra, 2017. p. 663-686. p. 672. Para além das obras supracitadas, para uma análise detalhada destas questões, inclusive com distintas propostas de solução, conferir: CANESTRARO, Anna Carolina. As investigações internas no âmbito do criminal compliance e os direitos dos trabalhadores: considerações sobre a possibilidade de investigar e a transferência de informações para o processo penal. São Paulo: IBCCRIM, 2020. p. 95 e ss.; MIRANDA, Matheus de Alencar e. (In)eficiência de compliance e os direitos dos trabalhadores: evitando o "bode expiatório”. São Paulo: LiberArs, 2019. p. 287-288.

Cumpre destacar que caso admitidas em processo penal as provas advindas de investigações internas, elas serão apresentadas, via de regra, na forma de documentos, sendo assim, provas pré-constituídas. A exceção a esta regra nos parece residir na hipótese das declarações de testemunhas, das vítimas e do próprio suspeito, os quais, independentemente de terem sido ouvidos ou não nestes procedimentos privados, deverão novamente sê-lo em juízo, em respeito ao contraditório, não bastando, assim, a mera transferência ao processo penal, dos relatórios de entrevistas. Sobre a distinção entre provas pré-constituídas e provas constituendas, conferir com detalhes em: TARUFFO, Michele. La prueba de los hechos. Traducción de Jordi Ferrer Beltrán. 2. ed. Madrid: Editorial Trotta, 2005. p. 378. Sobre a desproporcionalidade da transferência dos relatórios de entrevistas e a consequente necessidade de repetição da oitiva, conferir com detalhes em: CANESTRARO, Anna Carolina. Op. Cit., p. 93-94. No mesmo sentido: ROXIN, Imme. Problemas e estratégias da consultoria de compliance em empresas. Revista Brasileira de Ciências Criminais, São Paulo, v. 23, n. 114, p. 321-339, mai./jun. 2015. p.334. 
dos elementos probatórios colhidos nas investigações internas, se estas são conduzidas, na maior parte das vezes, de maneira dissociada dos órgãos oficiais de investigação ${ }^{63}$. Em outras palavras, impõe-se o questionamento sobre se há meios para certificar que os elementos colhidos nestes procedimentos serão integralmente os mesmos que serão eventualmente apreciados em juízo, como meios de prova.

Parece-nos que a solução deste problema seria um pouco menos complexa, se a empresa não assumisse no processo penal, uma posição "bifronte", no sentido de que, independentemente de ser acusada ou vítima no caso concreto ${ }^{64}$, ela poderá atuar visando tão somente infirmar os fatos que contra si são imputados, focando em uma defesa "passiva" ou "negativa", ou poderá também atuar como uma longa-manus estatal, colaborando com os órgãos estatais de persecução penal ${ }^{65}$.

\section{Cadeia de Custódia da PROVA: conceito, fundamentos E RELEVÂNCIA PROCESSUAL PENAL}

A "cadeia de custódia da prova” pode ser conceituada como:

... um procedimento documentação ininterrupta, desde o encontro da fonte de prova, até sua juntada no processo, certificando onde,

63 Neste sentido, Ana Pais destaca os riscos derivados da utilização em processo penal, de elementos colhidos por operadores não judiciários, em circunstâncias desconhecidas, ou, ao menos, não controladas. Conferir com detalhes em: PAIS, Ana. Op. Cit., p. 671.

64 Neste ponto, cumpre mencionar a categorização apresentada por Eduardo Saad-Diniz, no plano da compreensão do comportamento corporativo socialmente danoso, que distingue os casos de: I) vitimização pela empresa (que avalia as causas e consequências do comportamento corporativo socialmente danoso, gerando processos de vitimização social); II) vitimização contra a empresa; e III) vitimização dentro da empresa. Cfr. detalhadamente em: SAAD-DINIZ, Eduardo. Vitimologia corporativa. São Paulo: Tirant lo Blanch, 2019. p. 152.

Sobre esta "aliança" entre as empresas - através de seus programas de compliance - e a administração estatal de justiça, através da qual aquelas auxiliam na realização da justiça e na busca da descoberta da verdade, visando a obtenção de vantagens, tais como a isenção ou atenuação da responsabilidade penal ou administrativa, a não promoção processual ou a não aplicação de medidas cautelares: ANTUNES, Maria João. Privatização das investigações..., p. 119-120. 
como e sob a custódia de quais pessoas e órgãos foram mantidos tais traços, vestígios ou coisas, que interessam à reconstrução histórica dos fatos no processo ${ }^{66}$.

Trata-se, assim, de um importante instrumento para a constatação da integralidade, identidade e autenticidade dos vestígios ou indícios delitivos, visando garantir a retidão do "caminho" percorrido até a conversão em evidência probatória. Cada pessoa que tivera contato com o elemento colhido se torna uma espécie de "garante" de sua conservação, razão pela qual é imperiosa a documentação deste percurso ${ }^{67}$.

É por essa razão, inclusive, que se fala na necessidade de observação da mismidad da prova, ou seja, de que aquilo que for submetido a juízo para apreciação e valoração, seja o mesmo que fora apreendido, sem contaminações, substituições, manipulações ou alterações ${ }^{68}{ }^{69}$. Ademais, ao se viabilizar às partes uma maior rastreabilidade das fontes de prova, o Acusado consequentemente terá maiores possibilidades de aferir se

66 BADARÓ, Gustavo. A cadeia de custódia e sua relevância para a prova penal. In: SIDI, Ricardo; LOPES, Anderson Bezerra (orgs.). Temas atuais da investigação preliminar no processo penal. 1. Reimp. Belo Horizonte: Editora D’Plácido, 2018. 517-538. p. 523.

FIGUEROA NAVARRO, María del Carmen. El aseguramiento de las pruebas y la cadena de custodia. La ley penal: revista de derecho penal, procesal y penitenciario, Madrid, v. 8, n. 84, p. 5-14, jul./ago. 2011. p. 7. Ibidem, p. 7.

69 A importância da documentação da cadeia como instrumento para assegurar a "mesmidade" da prova passou a ser observada pelo Tribunal Supremo Espanhol a partir da decisão de 2009, senão vejamos: "En relación a la cadena de custodia el problema que se plantea es garantizar que dado que se recogen los vestigios relacionados con el delito hasta que llegan a concretarse como pruebas en el momento del juicio, aquello sobre lo que recaerá la inmediación, publicidad y contradicción de las partes y el juicio de lo juzgado es lo mismo. Es a través de la cadena de custodia como le satisface la garantía de la "mismidad" de la prueba. Se ha dicho por la doctrina que la cadena de custodia es una figura tomada de la realidad a la que tiñe de valor jurídico con el fin de en su caso, identificar el objeto intervenido, pues al tener que pasar por distintos lugares para que se verifiquen los correspondientes exámenes, es necesario tener la seguridad de lo que se traslada y analiza es lo mismo en todo momento, desde que se recoge del lugar del delito hasta el momento final que se estudia, y en su caso, se destruye" (TRIBUNAL SUPREMO. SALA DE LO PENAL. STS 7710/2009. Ponente: Juan Ramon Berdugo Gomez de la Torre. 03.12.2009. Disponível em: <http://www.poderjudicial.es/search/index.jsp\#>. Acesso em 25 de junho de 2020). 
essas foram obtidas dentro dos limites da legalidade, e em caso de resposta negativa, terá concretas condições de impugná-las, exercendo de maneira efetiva seu direito de defesa.

É neste sentido, inclusive, que Geraldo Prado sustenta a especial importância deste instituto frente à "vulgarização" do apelo aos métodos ocultos de investigação, tais como as interceptações e escutas telefónicas, os procedimentos de vigilância contínua e as quebras de sigilo ${ }^{70}$. Diante do elevado nível de intromissão destes meios na vida privada e de suas potenciais violações a direitos e garantias dos investigados - o que justifica, inclusive, a estrita regulamentação destes institutos -, mostra-se imperiosa a viabilização de controles epistêmicos no processo penal, visando assegurar que a admissão e valoração dos elementos colhidos sejam condicionadas à observação das hipóteses e procedimentos legalmente previstos.

Muito embora seja geralmente associada à prova científica laboratorial, a necessidade de documentação da cadeia é mais ampla e pode estar relacionada à qualquer fonte de prova "real", uma vez que ela deverá ser coletada e levada ao processo através de um meio de prova, tal como a juntada de documentos ou a realização de perícias. Pode-se falar também, em cadeia de custódia de elementos imateriais, tais como registros eletrônicos, conversas telefónicas, e-mails, mensagens de voz, fotografias, vídeos da internet, dentre outros. De todo modo, mostrar-se-á necessário um rigoroso registro de todas as pessoas que tiveram os elementos de prova sob o seu poder físico, desde sua coleta até a apresentação em juízo ${ }^{71}$.

Uma vez podendo ser considerado o "princípio síntese" do processo penal, o devido processo legal se mostra como o mais básico fundamento da obrigatoriedade de observância da cadeia de custódia da prova $^{72}$, englobando em seu cerne, as garantias a um processo desenvolvido

70 PRADO, Geraldo. A cadeia de custódia da prova no processo penal. São Paulo: Marcial Pons, 2019. p. 68.

71 BADARÓ, Gustavo. A cadeia de custódia..., p. 522.

72 Neste sentido: VALENTE, Manuel Monteiro Guedes. Cadeia de custódia da prova. 2. ed. Coimbra: Almedina, 2020. p. 48-51. 
perante um juiz natural, em contraditório e com respeito à ampla defesa, à presunção de inocência e à motivação das decisões ${ }^{73}$.

Mais especificamente, pauta-se este instituto, em primeiro lugar, na tutela do contraditório, designadamente com relação à própria obtenção extraprocessual da fonte de prova, viabilizando às partes, a contestação não apenas da sua legalidade, mas também dos métodos utilizados e de sua própria integralidade e credibilidade. Neste sentido, o desrespeito a determinado procedimento no momento da coleta, manipulação ou transporte do elemento probatório afetará sua fidedignidade, fato que poderá ser constatado e alegado pela parte interessada ${ }^{74}$.

Conforme explica Badaró, o contraditório é uma garantia processual fundamental, não apenas por viabilizar às partes o conhecimento e a reação aos atos que lhes sejam desfavoráveis ${ }^{75}$, mas também por permitir o funcionamento de uma estrutura dialética nas atividades processuais e consequentemente, exercer uma importante função heurística ${ }^{76}$, no sentido de ser uma garantia epistemológica que amplia os limites de

73 Essa noção de devido processo legal como princípio síntese do processo penal é apresentada em: BADARÓ, Gustavo Henrique. Processo penal. 8. ed. rev., atual. e ampl. São Paulo: Thomson Reuters Brasil, 2020. p. 97. No Brasil, a Constituição Federal prevê expressamente que: "Art. $5^{\circ}$ [...] LIV - ninguém será privado da liberdade ou de seus bens sem o devido processo legal;" (BRASIL. Constituição da República Federativa do Brasil de 1988. Disponível em: <http://www.planalto.gov.br/ccivil_03/constituicao/constituicao.htm>. Acesso em 29 de junho de 2020). Em Portugal, o Código de Processo Penal prevê em seu Art. $2^{\circ}$, que "Artigo 2. ${ }^{\circ}$ Legalidade do processo. A aplicação de penas e de medidas de segurança criminais só pode ter lugar em conformidade com as disposições deste Código" (PORTUGAL. DL n. ${ }^{\circ}$ 78/87, de 17 de fevereiro: Código de Processo Penal. Disponível em: <http://www.pgdlisboa. pt/leis/lei_mostra_articulado.php?tabela=leis\&artigo_id=199A0002\&nid=199\&nversao=\&tabela=leis\&so_miolo=>. Acesso em 29 de junho de 2020).

74 MENEZES, Isabela A.; BORRI, Luiz A.; SOARES, Rafael J. A quebra da cadeia de custódia da prova e seus desdobramentos no processo penal brasileiro. Revista Brasileira de Direito Processual Penal, Porto Alegre, v. 4, n. 1, p. 277-300, jan./abr. 2018. p. 284. BADARÓ, Gustavo Henrique. Processo penal..., p. 60-61.

76

Destacando a estreita vinculação entre o contraditório, nos termos aqui sustentados, e o direito à prova como condição para demonstrar a veracidade dos fatos narrados pelas partes: BADARÓ, Gustavo Henrique. Epistemologia judiciária e prova penal. $2^{\text {a }}$. tiragem. São Paulo: Thomson Reuters Brasil, 2019. p. 36-43. 
conhecimento do julgador sobre os fatos relevantes e diminui as possibilidades de $\operatorname{erros}^{77}$.

Ora, e mesmo nos âmbitos em que há maior presunção de credibilidade das provas, tais como nas científicas e até mesmo nas digitais, é importante a observação de um contraditório duplo, qual seja, não apenas sobre o seu conteúdo propriamente dito, mas também quanto à sua própria admissibilidade, sendo ele pautado na possibilidade de controle da fonte de prova $^{78}$.

Estritamente relacionada ao contraditório ${ }^{79}$, podemos também considerar a garantia à ampla defesa como um dos fundamentos do instituto aqui analisado. Conforme explicam Grinover, Gomes Filho e Scarance Fernandes, esses dois institutos estão intimamente interligados, uma vez que é do contraditório (visto em seu primeiro momento, da informação) que surge o direito de defesa, mas é esta, como correlata ao poder de ação, que garante o contraditório. Em outras palavras, a defesa assegura o contraditório, mas é também por ele que se manifesta e é garantida ${ }^{80}$.

No plano da rastreabilidade das fontes probatórias, já salientamos a importância da documentação da cadeia como, quiçá, a única possibilidade concreta do Acusado, de impugnar a coleta e o transporte dos elementos, bem como os métodos científicos empregados para tanto, apresentando, na oportunidade, as provas que entender cabíveis.

77 BADARÓ, Gustavo Henrique. Processo penal..., p. 62.

78 Neste sentido, com múltiplas citações: MENDES, Carlos Hélder Carvalho Furtado. Dado informático como prova penal confiável(?): apontamentos procedimentais sobre a cadeia de custódia digital. Revista Brasileira de Ciências Criminais, São Paulo, v. 27, n. 161, p. 131-161, nov. 2019. p. 151.

79 Exemplificativa neste ponto é a lição de Ferrajoli, que sustenta ser a defesa que outrora não possuía espaço em processos inquisitórios - o mais importante instrumento de controle da atividade probatória acusatória, especialmente mediante o contraditório entre teses acusatórias e defensivas e suas respectivas provas e contraprovas. Conferir com detalhes em: FERRAJOLI, Luigi. Diritto e ragione: teoria del garantismo penale. Roma: Editori Laterza, 2004. p. 629.

80 GRINOVER, Ada Pellegrini; GOMES FILHO, Antonio Magalhães; FERNANDES, Antonio Scarance. As nulidades no processo penal. 12. ed. rev. e atual. São Paulo: Editora Revista dos Tribunais, 2011. p. 71. 
Neste sentido, conforme explica Geraldo Prado, o rastreamento da legalidade da atividade persecutória e o consequente repúdio aos possíveis excessos acusatórios só é possível, muitas vezes, com o conhecimento, por parte da defesa, da totalidade dos elementos informativos colhidos ao longo da investigação $0^{81}$.

Assim, a concretização de uma efetiva ampla defesa fica a depender, neste ponto, do acesso ao registro dos procedimentos e métodos empregados, bem como da cronologia e das pessoas que tiveram contato com as evidências, razão pela qual é fundamental sua conservação.

Um dos principais fundamentos reside ainda, na necessidade de controles epistêmicos na justiça criminal, controles estes instituídos pelo legislador através da definição de hipóteses de admissibilidade ou inadmissibilidade probatória, regramento da produção dos meios de prova, definição das hipóteses e limites dos meios de obtenção de provas e, residualmente, definição dos limites ao livre convencimento em reforço à presunção de inocência ${ }^{82}$. Na base desta pretensão se encontra uma epistemologia judiciária garantista, que busca assegurar um princípio de estrita jurisdicionalidade, que tenha como condições: a) a verificabilidade ou falsificabilidade das hipóteses acusatórias; e b) a sua prova empírica, mediante um processo que permita sua verificação e eventual refutação ${ }^{83}$. Porém, esses limites epistêmicos não bastam, mostrando-se também necessários limites legais à atividade probatória, para a preservação de valores não necessariamente conexos com a descoberta da verdade, mas sim relacionados à dignidade humana e às liberdades individuais ${ }^{84}{ }^{85}$.

81 PRADO, Geraldo. Op. Cit., p. 65.

82 BADARÓ, Gustavo Henrique. A cadeia de custódia..., p. 521.

83 FERRAJOLI, Luigi. Op. Cit., p. 8.

84 BADARÓ, Gustavo Henrique. A cadeia de custódia..., p. 520.

85 Conforme leciona Gomes Filho, os limites probatórios aqui mencionados podem ter fundamentos extraprocessuais, tais como a vedação de provas obtidas mediante a violação de direitos fundamentais, ou processuais, quando são excluídas, por exemplo, provas impertinentes, irrelevantes ou que possam levar o julgador a um juízo equivocado. Conferir em: GOMES FILHO, Antonio Magalhães. Direito à prova no processo penal. 1. ed. São Paulo: Revista dos Tribunais, 1997. p. 93. 
Em último termo, assim, a documentação da cadeia de custódia e os possíveis efeitos processuais de sua "quebra" visam assegurar que o direito subjetivo à prova não seja absoluto, uma vez que suas eventuais restrições, em última análise, asseguram o direito dos demais interessados, à uma prova corretamente obtida, produzida e valorada. Em outras palavras, "ao direito à prova corresponde, como verso da mesma medalha, um direito à exclusão das provas que contrariem o ordenamento"86_87.

Muito embora se trate de uma construção doutrinária e jurisprudencial de grande relevo no ordenamento jurídico norte-americano, caracterizado por seu procedimento adversarial e pelos mecanismos de discovery nas fases pré-processuais ${ }^{88}$, a cadeia de custódia da prova tem

86 Ibidem, p. 93.

87 É importante destacar que, no que tange especificamente ao ordenamento jurídico português, a doutrina majoritária entende restar prejudicada a caracterização do processo penal como um processo de partes, dentre outras razões, por estar a atuação do Ministério Público orientada pelo princípio da legalidade. Neste sentido, por todos: ANTUNES, Maria João. Direito processual penal. Coimbra: Almedina, 2016. p. 31-32; DIAS, Jorge de Figueiredo. Direito processual penal. 1. ed. reimp. Coimbra: Coimbra Editora, 2004. p. 239 e ss.; ANDRADE, Manuel da Costa. Sobre as proibições de prova no processo penal. Coimbra: Coimbra Editora, 1992. p. 206. Este entendimento nos faz questionar a idoneidade deste específico último fundamento (direito da "parte contrária” à uma prova lícita) para sufragar a importância de controles epistêmicos no processo penal português. Contudo, ainda que certamente não possamos (e nem pretendamos) descaracterizar todo um sistema processual penal para atender a um específico nicho de casos, parece-nos que, conforme melhor abordaremos no último tópico, os processos penais que tenham como arguidas pessoas coletivas, muitas vezes apresentam singularidades que acabam por se somar aos demais fundamentos supramencionados (contraditório, ampla defesa e devido processo legal) e tornar imperiosos estes controles, mesmo em um sistema acusatório misto. Com isso queremos dizer que, a crescente possibilidade de que um dos Arguidos (pessoa coletiva) promova investigações preliminares e aponte provas que possam ser prejudiciais a outro Arguido (pessoa singular), faz com que o processo penal assuma, ao menos destes casos, algumas características de um processo de partes.

Conforme explica Taruffo, nos ordenamentos jurídicos de Common Law, nomeadamente na fase preliminar do processo, os mecanismos de Discovery exercem a importante função de permitir que uma das partes conheça os elementos de prova que estão na posse da outra. Trata-se de uma obrigação que, nos Estados Unidos, abrange todos os meios de prova relevantes ao assunto em causa (com exceção daqueles protegidos por privilégios) e que permite, em último termo, a definição dos fatos que fundamentam a demanda ou a 
ganhado relevo legislativo também nos ordenamentos jurídicos de civil law. É o que se observa, por exemplo, no "Capítulo V" do Código de Procedimiento Penal de Colombia, que em seus Artigos 254 e subsequentes, regulamenta especificamente a cadeia de custódia ${ }^{89}$.

O ordenamento jurídico brasileiro também passou a prever expressamente a cadeia de custódia da prova no Código de Processo Penal, especialmente após as modificações inseridas pela Lei 13.964/2019 (Lei Anticrime $)^{90}$. Em seus Artigos 158-A e subsequentes, observamos não apenas o conceito deste instituto, como ainda a regulamentação das etapas e de alguns procedimentos a serem observados ${ }^{91}$. É verdade porém, que

defesa. Neste sentido: TARUFFO, Michele. La prueba. Traducción de Laura Manríquez y Jordi Ferrer Beltrán. Madrid: Marcial Pons, 2008. p. 118-120. Os mecanismos de discovery estão expressamente previstos na Rule 16, das Federal Rules of Criminal Procedure, podendo ser consultados em: UNITED STATES. Federal Rules of Criminal Procedure. As amended to December 1, 2019. Disponível em: <https://www.law.cornell.edu/rules/frcrmp >. Acesso em 26 de junho de 2020. Conferir ainda, sobre o tema e suas influências nos controles epistêmicos: PRADO, Geraldo. Op. Cit., p. 72-86.

Conferir com detalhes em: COLOMBIA. Código de Procedimiento Penal Colombiano (Ley 906 de 2004). Disponível em: <http://perso.unifr.ch/derechopenal/ assets/files/legislacion/1_20190708_03.pdf>. Acesso em 26 de junho de 2020.

Sobre os aspectos positivos e deficitários desta alteração legislativa, conferir: VIEIRA, Antonio. A cadeia de custódia da prova no processo penal: algumas notas sobre as alterações promovidas pela Lei 13.964/2019 (Pacote Anticrime). Trincheira Democrática: Boletim do Instituto Baiano de Direito Processual Penal, ano 3, n. 7, p. 27-32, fev./2020. p. 30 e ss. Para uma análise da jurisprudência do Superior Tribunal de Justiça anterior à aprovação da Lei Anticrime, conferir: ÁVILA, Gustavo Noronha de; BORRI, Luiz Antonio. A cadeia de custódia da prova no "Projeto de Lei Anticrime": suas repercussões em um contexto de encarceramento em massa. Revista Direito Público, v. 16, n. 89, p. 114-132, set./out. 2019. p. 121-124.

${ }^{91}$ Destacamos: "Art. 158-A. Considera-se cadeia de custódia o conjunto de todos os procedimentos utilizados para manter e documentar a história cronológica do vestígio coletado em locais ou em vítimas de crimes, para rastrear sua posse e manuseio a partir de seu reconhecimento até o descarte. $\S 1^{\circ} \mathrm{O}$ início da cadeia de custódia dá-se com a preservação do local de crime ou com procedimentos policiais ou periciais nos quais seja detectada a existência de vestígio. $\S 2^{\circ} \mathrm{O}$ agente público que reconhecer um elemento como de potencial interesse para a produção da prova pericial fica responsável por sua preservação. $\S 3^{\circ}$ Vestígio é todo objeto ou material bruto, visível ou latente, constatado ou recolhido, que se relaciona à infração penal" (BRASIL. Lei $n^{\circ}$ 13.964, de 24 de dezembro de 2019: aperfeiçoa a legislação penal e processual 
a redação adotada pelo legislador fora bastante restritiva, seja por fazer recair a cadeia de custódia tão somente sobre "vestígios materiais", nos termos do $\S 3^{\circ}$. - desconsiderando, assim, toda uma sorte de elementos de prova imateriais que mereciam resguardo -, seja por seu silêncio quanto aos efeitos da não preservação da cadeia e ao momento processual de sua apreciação ${ }^{92}$.

Cumpre destacar que, quando usualmente se fala em violação ou "quebra" da cadeia de custódia, não é propriamente a cadeia que fora rompida, mas sim, a sua documentação. Em outras palavras, sendo a "cadeia de custódia", propriamente dita, o conjunto de pessoas que tiveram contato com a fonte de prova e seus respectivos momentos específicos, ela não é passível per se de ser violada, mas sim, pode haver uma elipse no seu registro ${ }^{93}$.

Uma vez que sem essa documentação torna-se questionável a autenticidade e integridade da fonte, bem como e consequentemente, dos elementos de prova dali extraídos, ganha especial relevo no âmbito das investigações internas e do eventual aproveitamento em processo penal ${ }^{94}$,

penal. Disponível em: <http://www.planalto.gov.br/ccivil_03/_Ato20192022/2019/Lei/L13964.htm\#art3>. Acesso em 26 de junho de 2020).

92 MATIDA, Janaina. A cadeia de custódia é condição necessária para a redução dos riscos de condenações de inocentes. Boletim IBCCRIM, ano 28, n. 331, p. 6-9, jun./2020. p. 7-8. Para uma detida análise dos procedimentos previstos pelo novo regime, conferir em: DEZEM, Guilherme Madeira; SOUZA, Luciano Anderson de. Comentários ao pacote anticrime: Lei 13.964/2019. São Paulo: Thomson Reuters Brasil, 2020. p. 117-123.

93 BADARÓ, Gustavo Henrique. A cadeia de custódia..., p. 524.

94 Ainda que não seja possível uma análise minuciosa dos fundamentos e das limitações deste posicionamento e conforme já é possível se depreender dos próprios objetivos do presente trabalho, sustentamos que, a princípio, os elementos de informação advindos dos programas de compliance são admissíveis em processo penal, especialmente quando apresentadas pela pessoa jurídica em sua própria defesa. Um entendimento contrário, ao nosso ver, iria de encontro ao direito de defesa e ao direito à prova da pessoa jurídica acusada, bem como afetaria a própria funcionalidade dos programas de compliance, sendo um fator de desincentivo à adoção destes mecanismos. Questão bem mais tortuosa é a de saber se serão igualmente admissíveis estes elementos, quando apresentados pela Acusação, em desfavor de um outro Acusado (tais como um empregado ou colaborador) ou até mesmo quando apresentadas pela defesa da corporação, mas em desfavor daquele. Nesta última hipótese, inclusive, estariam em jogo os direitos de defesa de ambos 
os Acusados, para além, é claro, das garantias ao contraditório e ao devido processo legal do sujeito afetado pela prova. Se por um lado, os programas de compliance, de fato, exercem um importante papel de colaboração para com a administração da justiça, por outro, não podemos abstrair do fato de que estes procedimentos são conduzidos em âmbito privado e sem contraditório judicial. A despeito da necessidade de maior desenvolvimento destas ideias, algumas premissas iniciais, ao nosso ver, já podem ser propostas para discussão, sendo elas: I) estes elementos serão admissíveis quando apresentados pelo Acusado, no exercício do seu direito de defesa, podendo ser plenamente valorados para este fim, ressalvadas, é claro, as hipóteses a serem analisadas caso a caso, em que haja ilicitude na sua obtenção (p. ex., tortura de um terceiro). II) Sejam eles apresentados pela Acusação ou pelo Corréu, estes elementos jamais poderão fundamentar, por si só, uma condenação. Entre a plena valoração e a inadmissibilidade, essa seria uma solução intermédia, que visaria atender aos interesses relacionados à funcionalidade das investigações internas, em seu viés colaborativo para com o Estado, na descoberta da verdade, mas sem desatender ao direito dos eventuais afetados, ao devido processo legal e ao contraditório. Em um regime análogo ao dos elementos de informação advindos das investigações preliminares, os documentos provenientes destes procedimentos privados serão suficientes tão somente para fundamentar a abertura de um inquérito oficial ou a apresentação de uma denúncia. Sobre este ponto específico, conferir: CANESTRARO, Anna Carolina. Op. Cit., p. 95 e ss.. III) em consequência da primeira premissa, um documento advindo de investigações internas, apresentado pela pessoa jurídica acusada, ainda que em sua defesa, não poderá ser valorado para fins de fundamentar a condenação de outro Acusado. Há, ao nosso ver, dois possíveis caminhos passíveis de serem discutidos, para a conciliação entre o direito de defesa de ambos os Acusados nestas hipóteses: a) o primeiro, seria o de considerar que, muito embora pessoas físicas e jurídicas gozem do direito de defesa e das garantias a ele atinentes, estes direitos não necessariamente teriam o mesmo "peso". Neste sentido, conferir: ANTUNES, Maria João. Privatização das investigações..., p. 126-127. Assim, estando em conflito os direitos de defesa da pessoa física e jurídica, os da primeira gozariam de certa primazia, seja em razão da relativização admitida quantos a essas últimas, em razão de sua natureza (cfr. Art. $12^{\circ}$., 2, Constituição da República Portuguesa), seja pela própria vinculação de alguns direitos processuais, não apenas com as garantias relacionadas ao equilíbrio processual, mas também para com a própria dignidade humana, a qual não seria extensível às pessoas coletivas. Sobre esta questão, especificamente no que toca ao direito à não autoincriminação: NEIRA PENA, Ana María. La instrucción de los procesos penales frente a las personas jurídicas. Valencia: Tirant lo Blanch, 2017. p. 235 e ss.. b) A segunda hipótese seria o uso da faculdade prevista pelos Art. $30^{\circ}$ do Código de Processo Penal Português e Art. 80 do Código de Processo Penal Brasileiro, os quais preveem a separação dos processos, admitindo, ambos os ordenamentos, essa possibilidade, por questões de conveniência, dentre as quais, a de graves riscos para os interesses do Acusado. 
dos elementos nelas colhidos, o questionamento sobre como assegurar a inviolabilidade da cadeia de custódia quando, na base da descoberta das fontes de prova, encontram-se entes privados. Debruçar-nos-emos sobre esta problemática no tópico subsequente.

\section{RASTREABILIDADE DAS FONTES DE PROVA NAS INVESTIGAÇÕES INTERNAS: POSSIBILIDADES, FUNDAMENTOS E EVENTUAIS IMPLICAÇÕES DA SUA VIOLAÇÃO}

Conforme já mencionado ao longo do trabalho, de maneira idêntica à inexistência de previsões legais quanto à promoção ou não de uma investigação interna, há uma inconteste (e talvez justificada) lacuna no que toca aos eventuais deveres de documentação da recolha de evidências nestes procedimentos, constando estes, quando muito, nos manuais de compliance e demais normativas internas. Observa-se, porém, que apesar deste vazio legal, a documentação da cadeia de custódia da prova ${ }^{95}$ não apenas é possível, como já é observada e executada pela generalidade dos escritórios especializados neste âmbito, o que nos faz questionar quais seriam as razões de fundo para tanto.

A primeira dessas razões, ao nosso ver, diz respeito à submissão de muitas empresas, ao ordenamento jurídico norte-americano, por estarem listadas no mercado de valores local ou terem suas ações negociadas no "mercado de balcão" nos Estados Unidos, estando assim, submetidas

95 Cumpre-nos salientar aqui, a título de esclarecimento terminológico, que ao empregarmos o termo "cadeia de custódia da prova" no âmbito das investigações internas, o fazemos por fidelidade à forma pela qual o próprio instituto é conhecido na doutrina e jurisprudência. Não queremos com ele dizer, necessariamente, que todos os elementos colhidos neste âmbito das investigações internas reúnem as condições necessárias para serem considerados "provas" em sentido estrito, tal como previsto, por exemplo, no Artigo 155 do Código de Processo Penal Brasileiro, que assim considera somente aquelas produzidas em contraditório judicial. Conferir com detalhes em: BRASIL. Decreto-Lei $n^{o}$ 3.689, de 3 de outubro de 1941: Código de Processo Penal. Disponível em: <http://www.planalto.gov.br/ccivil_03/decreto-lei/del3689.htm>. Acesso em 26 de junho de 2020. 
às provisões da FCPA (Forreign Corrupt Practices Act) ${ }^{96}$. Ora, e sendo a cadeia de custódia, conforme já analisado, um instituto de primeira relevância neste sistema, uma eventual falta de cuidado por parte da pessoa coletiva, para com os registros das evidências por ela colhidas no âmbito de uma investigação interna, poderá prejudicar toda a estratégia defensiva da corporação em eventual processo em causa.

A segunda razão, intimamente relacionada com a supracitada, residiria no inconteste interesse empresarial na obtenção dos "benefícios" processuais já aqui analisados, os quais podem estar vinculados, muitas vezes, com a "utilidade" - do ponto de vista das entidades estatais de controle e persecução - dos elementos colhidos. Observa-se, por exemplo, que o Memorandum McNulty, do Departamento de Justiça dos Estados Unidos, prevê expressamente como um dos aspectos a serem considerados pelos Procuradores Federais, ao avaliarem o processamento ou não de uma pessoa jurídica, a sua voluntária e temporânea colaboração, sendo considerados como fatores negativos o atraso ou a incompletude no fornecimento dos dados ${ }^{97}$.

96 "Who Is Covered by the Anti-Bribery Provisions? The FCPA's anti-bribery provisions apply broadly to three categories of persons and entities: (1) "issuers" and their officers, directors, employees, agents, and shareholders; (2) "domestic concerns" and their officers, directors, employees, agents, and shareholders; and (3) certain persons and entities, other than issuers and domestic concerns, acting while in the territory of the United States. [...] How Can I Tell If My Company Is an "Issuer"? It is listed on a national securities exchange in the United States (either stock or American Depository Receipts); or the company's stock trades in the over-the-counter market in the United States and the company is required to file SEC reports" (CRIMINAL DIVISION OF THE U.S. DEPARTMENT OF JUSTICE; ENFORCEMENT DIVISION OF THE U.S. SECURITIES AND EXCHANGE COMMISSION. FCPA: a resource guide to the U.S. Foreign Corrupt Practices Act. 2012. Disponível em: < https://www.ganintegrity.com/portal/ anti-corruption-legislation/fcpa-foreign-corrupt-practices-act/>. Acesso em 26 de junho de 2020).

97 "VII. Charging a Corporation: The Value of Cooperation A. General Principle: In determining whether to charge a corporation, that corporation's timely and voluntary disclosure of wrongdoing and its cooperation with the government's investigation may be relevant factors. In gauging the extent of the corporation's cooperation, the prosecutor may consider, among other things, whether the corporation made a voluntary and timely disclosure, and the corporation's willingness to provide relevant evidence and to identify the culprits within the corporation, including senior executives. [...] Another factor to be weighed by 
Ora, essa perspectiva de análise dos programas de compliance em seu viés de colaboração para com a administração da justiça - sendo na prática, o departamento de compliance, muitas vezes enxergado como uma espécie de "extensão" do gabinete dos órgãos de controle e persecução ${ }^{98}$ - impõe às pessoas jurídicas e aos seus responsáveis pelo cumprimento normativo e pelas investigações internas, uma inegável preocupação para com a fiabilidade das provas colhidas, uma vez que, ainda que elas não sejam legalmente obrigadas a observar a documentação da cadeia de custódia, sua quebra poderá prejudicar os benefícios almejados pela corporação.

Por fim, não podemos abstrair de que a cargo das investigações internas, especialmente das realizadas em corporações de grande complexidade, encontram-se grandes escritórios e empresas de renome, cujo valor reputacional é um vetor importante a ser considerado. Com isso queremos dizer que, ainda que não sejam legalmente obrigadas a tanto, as responsáveis pela condução das investigações internas tendem a ser

the prosecutor is whether the corporation, while purporting to cooperate, has engaged in conduct intended to impede the investigation (whether or not rising to the level of criminal obstruction). Examples of such conduct include: [...] incomplete or delayed production of records; and failure to promptly disclose illegal conduct known to the corporation" (U.S. DEPARTMENT OF JUSTICE. OFFICE OF THE DEPUTY ATTORNEY GENERAL. Memorandum McNulty. Washington D.C., 2006. Disponível em: <https://www.justice.gov/sites/default/ files/dag/legacy/2007/07/05/mcnulty_memo.pdf $>$. Acesso em 23 de maio de 2020. p. 7; 12).

98 É importante salientar que de maneira alguma refratamos a importância do viés colaboracional dos programas de compliance para com a administração da justiça, uma vez que, em sendo eles um instrumento que visa, acima de tudo, a promoção de uma cultura de ética e de cumprimento normativo no cerne empresarial, seria totalmente despropositada a sua utilização como uma forma de obstaculizar a descoberta de ilícitos. Contudo, somos críticos a uma percepção unilateral destes mecanismos, que eventualmente os considera tão somente como instrumentos de facilitação da obtenção de dados que, de outra forma, estariam menos acessíveis ao Estado. Se por um lado os programas de compliance são ferramentas fundamentais para superação das constatadas dificuldades de enfrentamento da criminalidade empresarial, por outro, seu manejo encontra inultrapassáveis limites justamente ali, onde essas dificuldades persecutórias são originadas justamente dos direitos e garantias das pessoas físicas e jurídicas afetadas, cuja observância se impõe. 
zelosas para com a cadeia de custódia e sua respectiva documentação, uma vez que a credibilidade de seus serviços e até mesmo a eficácia do programa de compliance da empresa contratante estão em jogo.

Dito isso, surge o questionamento sobre como assegurar a inviolabilidade dos registros da cadeia de custódia de provas derivadas de investigações internas ${ }^{99}$. De maneira geral, observamos que as fontes de prova que apresentam potenciais maiores dificuldades são os exames técnicos (uma perícia em uma barragem ou em determinado equipamento da linha de produção, por exemplo) e os documentos digitais ${ }^{100}$, merecendo estes últimos, em razão de suas particularidades, maiores considerações.

As evidências digitais se destacam por sua imaterialidade, volatilidade, fragilidade ${ }^{101}$ e consequente facilidade de desaparecimento e contaminação ${ }^{102}$. Em outras palavras, há um grande risco de evidence dynamics, observada quando há alteração, realocação e obliteração da

99 Cumpre-nos salientar que, uma vez que os concretos métodos variarão de acordo com o setor de atuação da companhia e com o tipo de fonte de prova, nosso objetivo no presente tópico não é o de descrever o método científico a ser adotado pelo especialista no caso, mas tão somente apontar, a título exemplificativo, as fontes de informação que tendem a apresentar maiores dificuldades e possíveis medidas a serem adotadas para assegurar a rastreabilidade.

${ }^{100}$ Conforme destaca Sónia Fidalgo, a recolha de prova em ambiente digital não diz respeito tão somente ao domínio da chamada cibercriminalidade, podendo ser relevante para a apuração de fatos relativos a quaisquer crimes, mesmo àqueles que não foram cometidos em ambiente digital. Cfr.: FIDALGO, Sónia. A utilização da inteligência artificial no âmbito da prova digital - direitos fundamentais (ainda mais) em perigo. In: RODRIGUES, Anabela Miranda. Inteligência artificial no direito penal. Coimbra: Almedina, 2020. p. 129162. p. 132 e ss.

${ }^{101}$ Diz-se que a prova digital é imaterial porque ela necessita de um suporte físico para sua visualização, pois, do contrário, seria uma mera sequência de bits. Em decorrência desta imaterialidade, diz-se que ela é frágil e volátil, pois sua manipulação descuidada poderá ensejar a alteração de suas propriedades, bem como seu desaparecimento poderá decorrer de fatores como a falta de bateria do dispositivo ou a realização de uma nova gravação sobre a antiga. Neste sentido, com múltiplas citações: RAMALHO, David da Silva. Métodos ocultos de investigação criminal em ambiente digital. Coimbra: Almedina, 2017. Versão ebook. Não paginado. Capítulo II. Seção 2.2.

${ }^{102}$ Neste sentido, com múltiplas citações: RAMALHO, David da Silva. Op. Cit., N.P., Capítulo II. Seção 2.2; MENDES, Carlos Hélder Carvalho Furtado. Dado informático como prova penal confiável(?): apontamentos procedimentais 
prova, ainda que involuntárias ${ }^{103}$. Essa contaminação, aliás, pode se dar não apenas pelo contato físico inapropriado com o dispositivo ou suporte físico que contém o dado, mas também digitalmente ${ }^{104}$.

O primeiro passo recomendado para prevenir uma contaminação no momento do exame é a realização de uma cópia integral do sistema a ser periciado (bitstream copy), uma vez que a análise do próprio original coloca em risco sua integralidade e autenticidade. Neste procedimento de cópia, deve ser utilizado um write-blocker, evitando que um sistema informático introduza ou altere dados em outro com o qual ele esteja conectado ${ }^{105}$.

Todas as cópias devem ser validadas com o chamado Hash, que é um algoritmo aplicado a um determinado input, gerando um output codificado. Ao ser aplicado a certos documentos ou conjunto de dados digitais, é criado um código alfanumérico que funciona como uma espécie de "impressão digital". A aplicação do Hash ao mesmo conjunto de dados ou documentos gerará sempre o mesmo código, sendo possível, então, a partir dele, saber se houve ou não alteração nos dados analisados ${ }^{106}$.

$\mathrm{Na}$ análise das informações digitais, o investigador não poderá, ainda, abstrair da chamada metadata, ou "dados sobre dados", que contêm

sobre a cadeia de custódia digital. Revista Brasileira de Ciências Criminais, São Paulo, v. 27, n. 161, p. 131-161, nov. 2019. p. 136.

103 Conforme explica Eoghan Casey, os investigadores e peritos em evidências digitais raramente terão a oportunidade de examinar a "cena do crime digital” em seu estado original, devendo contar, portanto, com alterações, realocações, obliterações ou ocultações promovidas pelos suspeitos, vítimas, peritos, policiais ou quaisquer outros que tenham tido contato com os dados. Conferir em: CASEY, Eoghan. Foundations of digital forensics. In: CASEY, Eoghan (ed.). Digital Evidence and Computer Crime: forensic science, computers and the internet. 3. ed. Waltham, MA: Elsevier, 2011. p. 3-34. p. 27.

104 Sobre as modalidades "física" e "digital" de contaminação: MENDES, Carlos Hélder Carvalho Furtado. Dado informático como prova penal confiável(?): apontamentos procedimentais sobre a cadeia de custódia digital. Revista Brasileira de Ciências Criminais, São Paulo, v. 27, n. 161, p. 131-161, nov. 2019. p. 148-149; MARSHALL, Angus. Digital forensics: Digital Evidence in Digital Investigation. West Sussex, UK: Wiley-Blackwell, 2008. p. 41.

105 Neste sentido, com múltiplas citações: RAMALHO, David da Silva. Op. Cit., N.P., Capítulo II. Seção 3.2.

106 Ibidem, N.P., Capítulo II. Seção 3.2. 
informações muito importantes, tais como horário e data de modificação, pessoas que tiveram acesso ou que tinham permissão para tanto e até mesmo quem excluiu determinados arquivos ${ }^{107}$.

O National Institute for Standards and Technology propõe um modelo "quadripartite" para o procedimento de investigação em ambiente digital, consistente nas fases de I) recolha - que engloba a identificação, rotulagem e registro; II) exame; III) análise e IV) apresentação de relatório, o qual deverá necessariamente fazer constar cada passo relevante da investigação, tais como métodos, procedimentos, ferramentas, dentre outros ${ }^{108}$.

Desta sucinta análise e no que toca aos específicos interesses dos presente trabalho, é possível depreender que o especialista tem, no âmbito da obtenção de elementos digitais em investigações internas, não apenas o dever de colhe-los e manuseá-los de acordo com os procedimentos científicos aplicáveis, preservando sua integralidade e autenticidade, mas também a obrigação de registrar cada uma das etapas deste procedimento, para que constem os respectivos intervenientes, os específicos momentos de coleta e manuseio, os métodos empregados e o estado em que os dados foram obtidos. Essa documentação é fundamental no sentido de tentar assegurar a rastreabilidade destes elementos e viabilizar o acesso e eventual impugnação pelos interessados.

Estas considerações certamente serão válidas também para as demais espécies de evidências colhidas no âmbito de uma investigação interna, sendo que em cada qual, serão aplicados os respectivos procedimentos e metodologia científica, sendo crucial, em todo caso, a documentação e registro das etapas, métodos, cronologia e intervenientes.

Dito isso, observamos que não apenas é possível o devido registro da cadeia de custódia no âmbito das investigações internas, como também que se trata de uma diligência que já é observada nesta seara, ainda que

${ }^{107}$ Ibidem, N.P., Capítulo II. Seção 2.2.

${ }^{108}$ Este modelo pode ser consultado com detalhes em: NATIONAL INSTITUTE OF STANDARDS AND TECHNOLOGY - NIST. Guide to Integrating Forensic Techniques into Incident Response: Recommendations of the National Institute of Standards and Technology. 2006. Disponível em: <https://csrc.nist.gov/ publications/detail/sp/800-86/final>. Acesso em 27 de junho de 2020. Na doutrina, adotando esta classificação: RAMALHO, David da Silva. Op. Cit., N.P., Capítulo II, Seção 3.2. 
sem determinação legal. Questiona-se, porém, quais seriam as possíveis implicações processuais penais da violação da cadeia. Em outras palavras, seriam admissíveis em processo penal, elementos de prova colhidos em investigações internas, cuja rastreabilidade estivesse prejudicada?

Nesse escopo no qual as fontes de provas são descobertas não por órgãos estatais, mas sim por particulares que têm especial interesse nos fatos que elas podem vir a corroborar, deve prevalecer de maneira ainda mais acentuada, uma lógica de "desconfiança" sobre as provas ${ }^{109}$. É por esta razão que, ao nosso ver, a quebra da cadeia de custódia das evidências advindas destes procedimentos privados, não pode ser considerada irrelevante no plano processual penal, especialmente se vislumbramos que, para além de seu uso na instrução da defesa corporativa, estes documentos poderão vir a ser utilizados para corroborar uma pretensão acusatória em face de terceiros, tais como funcionários e colaboradores da empresa.

Afastada, assim, sua irrelevância, há duas possíveis consequências processuais penais para as provas cuja rastreabilidade esteja prejudicada: I) a prova seria ilegítima (ou proibida) ${ }^{110}$ - e portanto, inadmissível no

${ }^{109}$ Segundo Baytelman e Duce, uma vez que "provas materiais" - assim consideradas os objetos e documentos apresentados em juízo - são coletadas sem imediação do juiz e não estando sujeitas a um contraditório quando em seu estado original, deve sua produção em juízo estar regida por uma lógica de "desconfiança", a qual tem como consequência a necessidade de que estes objetos e documentos sejam "acreditados", ou seja, de que haja comprovação da sua correspondência com aquilo que são declarados. Conferir com detalhes em: BAYTELMAN A., Andrés; DUCE J., Mauricio. Litigación penal: juicio oral y prueba. 1. ed. Santiago: Ediciones Universidad Diego Portales, 2004. Paginação Irregular. Capítulo VII, Seção 1. Na mesma linha: PRADO, Geraldo. Ainda sobre a "quebra da cadeia de custódia das provas". Boletim IBCCRIM, ano 22, n. 262, p. 16-17, set./2014. p. 17.

${ }^{110}$ Sem prejuízo de outras classificações, a doutrina brasileira costuma distinguir no âmbito da "prova ilegal" - cuja obtenção se dera com violação de leis ou de princípios gerais do ordenamento -, as I) "provas ilegítimas”, quando a proibição for colocada por lei processual; e as II) "provas ilícitas”, quando a proibição for de cariz "material”. Neste sentido: GRINOVER, Ada Pellegrini et. al., Op. Cit., p. 126-127. A configuração da ilicitude se daria no momento da obtenção da prova, tendo como sanção processual a sua inadmissibilidade, devendo ser desentranhada dos autos, nos termos do Art. 157 do CPP. Já a ilegitimidade ocorreria na fase de produção da prova, tendo como sanção processual a sua nulidade, impondo, se possível, sua renovação, nos termos 
processo, devendo, se for o caso, ser desentranhada; ou então II) a prova poderia ser admitida, mas seria valorada de maneira atenuada a depender da situação ${ }^{111}{ }^{112}$.

A doutrina majoritária, especialmente a brasileira, vai no sentido da primeira solução, sustentando haver uma ilegalidade que deveria ensejar inadmissibilidade ou, se for o caso, exclusão da prova viciada

do Art. 573 do CPP. Neste sentido: GOMES FILHO, Antonio Magalhães. Provas: Lei 11.690, de 09.06.2008. In: MOURA, Maria Thereza Rocha de Assis (coord.). As reformas no processo penal: as novas Leis de 2008 e os projetos de reforma. São Paulo: Editora Revista dos Tribunais, 2008. p. 246-297. p. 266. Na doutrina portuguesa, por sua vez, é feita a distinção entre as "proibições de prova" e as "regras de produção de prova", sendo que na primeira categoria - consubstanciada como um verdadeiro limite à própria descoberta da verdade - estariam englobadas as proibições de produção da prova e as proibições de valoração da prova, sendo em todo caso, sua consequência, a ilicitude probatória. Já quanto às regras sobre a produção da prova, elas disciplinariam o procedimento exterior de sua realização, não implicando, porém, em proibição de valoração, mas sim, em responsabilização de quem a produziu, se for o caso. Neste sentido: ANDRADE, Manuel da Costa. Op. Cit, p. 83 e ss.. Na mesma linha, mas salientando que o dever de advertência do juiz, quanto à não obrigatoriedade do Arguido de responder as perguntas, seria uma verdadeira proibição de prova e não uma mera prescrição ordenativa: DIAS, Jorge de Figueiredo. Op. Cit., p. 446. Esta distinção parte da proposta de Gössel, de consideração das proibições probatórias como barreiras ao objeto sobre o qual poderá recair a sentença, barreiras estas que independem da etapa do procedimento preliminar ou processual penal em que houvera a violação do ordenamento jurídico. Conferir com detalhes em: GÖSSEL, Karl Heinz. As proibições de prova no direito processual penal da República Federal da Alemanha. Revista Portuguesa de Ciência Criminal, Coimbra, v. 2, n. 3, p. 397-441, jul./set. 1992, p. 439 e ss.; GÖSSEL, Karl Heinz. La prueba ilícita en el proceso penal. Revista de Derecho Penal, Buenos Aires, n. 1, p. 27-116, 2001, p. 104 e ss.

${ }^{111}$ Essas duas possibilidades são apresentadas em: BADARÓ, Gustavo Henrique. Processo penal..., p. 512.

112 Para Guilherme Madeira Dezem, três poderiam ser as consequências: a ilicitude da prova, quando a ilegalidade advenha de norma de direito material; a nulidade, quando advenha de norma de direito processual; ou o enfraquecimento da força probante. Neste sentido: DEZEM, Guilherme Madeira. Curso de processo penal. 6.ed. São Paulo: Thomson Reuters Brasil, 2020. Versão ebook. Não paginado. Capítulo 11. Seção 11.14.21. Ainda que teoricamente factível, observamos ser, na prática, pouco crível que a violação da documentação da cadeia de custódia advenha de uma norma de direito material. 
dos autos ${ }^{113}$. A recém aprovada Lei 13.964/19, conforme já salientamos, fora silente a respeito, havendo posicionamentos também, no sentido de que haveria nulidade pela não observância das regras relativas à cadeia de custódia, podendo, contudo, o órgão acusador - se for ele quem a produziu - comprovar que não houvera prejuízo e afastar a nulidade ${ }^{114}$. No ponto de vista da dinâmica processual, porém, uma vez que na maior parte das vezes a prova maculada já integrará o processo e o juízo quanto à sua ilicitude será feito a posteriori, não haverá diferenças concretas, ao menos no plano cronológico, entre o desentranhamento decorrente da inadmissibilidade e a nulidade ${ }^{115}$.

Esse posicionamento, porém, ainda que muito bem fundamentado na justificada preocupação de que provas de "baixa credibilidade" possam vir a influenciar a narrativa processual e possivelmente fundamentar uma condenação, enfrenta uma dificuldade adicional no específico âmbito que aqui analisamos. Conforme já sustentado ao longo do trabalho, as recentes tendências de "privatização das investigações" - escopo no qual inserimos, não apenas as investigações internas corporativas, quando analisadas sob o viés de sua potencial relação para com um processo penal, mas também as investigações defensivas como um todo - certamente potencializaram a possibilidade de que a quebra da cadeia de custódia seja ocasionada não pelos agentes estatais de investigação, mas sim, pela própria defesa e seus investigadores privados.

Neste caso, se por um lado o vício poderá recair sobre um elemento potencialmente prejudicial ao eventual Corréu, por outro, poderá

113 Neste sentido: PRADO, Geraldo. A cadeia de custódia..., p. 134; MATIDA, Janaina. Op. Cit., p. 8; EDINGER, Carlos. Cadeia de custódia, rastreabilidade probatória. Revista Brasileira de Ciências Criminais, São Paulo, v. 24, n. 120, p. 237-257, mai./jun. 2016. p. 252-254; MENDES, Carlos Hélder Carvalho Furtado. Op. Cit., p. 150. Também em Portugal, por todos: VALENTE, Manuel Monteiro Guedes. Op. Cit., p. 97-98.

${ }^{114}$ DEZEM, Guilherme Madeira; SOUZA, Luciano Anderson de. Op. Cit., p. 123124. Esta leitura a partir da ideia de "prejuízo" é viabilizada pela literalidade do Artigo 563 do Código de Processo Penal, que prevê: "Art. 563. Nenhum ato será declarado nulo, se da nulidade não resultar prejuízo para a acusação ou para a defesa" (BRASIL. Decreto-Lei $n^{\circ} 3.689$, de 3 de outubro de 1941: Código de Processo Penal. Disponível em: <http://www.planalto.gov.br/ccivil_03/decreto-lei/del3689.htm>. Acesso em 26 de junho de 2020).

115 BADARÓ, Gustavo Henrique. Processo penal..., p. 455. 
ser relativo a dado fundamental para a defesa da pessoa jurídica e até mesmo das pessoas singulares eventualmente implicadas. Dito isso, seja qual for a solução adotada - de inadmissibilidade ou não - podemos nos questionar sobre qual seria a resposta para o caso em que a ilicitude ou irregularidade ocorresse em prova favorável a um ou mais Acusados. Poderia ela ser admitida e valorada?

Ora, a partir do segundo entendimento doutrinário exposto acima, qual seja, o da admissão da prova e eventual atenuação de sua credibilidade na fase de valoração, a solução mais adequada seria a de remeter este juízo para o âmbito da valoração da prova, especialmente nos casos em que haja irregularidades ou omissões leves, sem indicativos concretos de substituição, adulteração ou modificação da fonte de prova. Mas também nas hipóteses mais contundentes, com vícios mais graves e maiores dúvidas quanto à autenticidade ou integridade da fonte de prova, esse juízo seria feito pelo julgador, de maneira mais rigorosa, no momento da valoração ${ }^{116}{ }^{117}$.

Os fundamentos desta linha, conforme explica Badaró, residiriam no entendimento de que as irregularidades na cadeia de custódia não seriam suficientes para ensejar a ilicitude probatória, uma vez que essa documentação da cadeia não seria a "prova” propriamente dita, mas sim,

116 BADARÓ, Gustavo Henrique. A cadeia de custódia..., p. 535. Em sentido próximo, Paolo Tonini e Carlotta Conti sustentam que, ao invés de declarar de pronto a inutilizzabilità, o controle do juiz sobre as fases do procedimento adotado e sobre a própria autenticidade da evidência poderá ser exercido, em contraditório de partes e levando sempre em conta as particularidades do caso, seja a partir de máximas da experiência, seja através do recurso a leis científicas. Conferir com detalhes em: TONINI, Paolo; CONTI, Carlotta. Il diritto delle prove penali. Prima edizione aggiornata. Milano: Giuffrè Editore, 2012. p. 334-335.

$117 \mathrm{O}$ direito à prova se manifesta nos seguintes momentos: I) o direito à investigação, que engloba a faculdade de procurar e descobrir provas; II) o direito de proposição de provas, referente à indicação e requerimento de provas, que podem ou não ser admitidas, de acordo com sua licitude, pertinência e relevância; III) o direito à produção de provas, através do qual se assegura aos interessados a participação no ato de produção dos meios de prova; e por fim, um IV) direito à valoração das provas, não podendo o julgador ignorar elementos de informação constantes dos autos. Conferir com detalhes em: GOMES FILHO, Antonio Magalhães. Direito à prova..., p. 88-89. Em sentido próximo: BADARÓ, Gustavo Henrique. Processo penal..., p. 446-447. 
uma "prova sobre a prova", cuja finalidade não seria a de demonstrar a veracidade ou falsidade das afirmações sobre os fatos, mas sim, assegurar a autenticidade e integridade da fonte da prova ${ }^{118}$.

Ainda que considerados os riscos dessa opção, a remessa dessa avaliação para um momento posterior viabilizaria ao julgador uma apreciação da gravidade e extensão da "quebra", das dúvidas que ela eventualmente enseja quanto ao elemento probatório e do concreto valor a lhe ser atribuído. Essa liberdade de apreciação, se por um lado poderia gerar um receio de eventuais arbitrariedades e redução da segurança jurídica, por outro, seria uma imperiosidade decorrente da maior participação ativa da defesa nas investigações, impedindo que esta viesse a ter inadmitidos elementos probatórios que poderiam lhe ser favoráveis. Ademais, não podemos nos abstrair do fato de que, em razão da imperiosidade da motivação das decisões, o concreto valor atribuído a um meio de prova cuja cadeia de custódia fosse violada certamente deveria constar da decisão e, em sendo o caso, poderia ser impugnado através dos competentes recursos.

Caso assim entendêssemos, as normas referentes à cadeia de custódia e sua documentação seriam, na linha da supramencionada categorização proposta por Costa Andrade ${ }^{119}$, regras sobre a própria produção da prova, sendo que sua eventual violação faria diminuir sua credibilidade mas não implicaria necessariamente em ilicitude probatória e consequente inadmissibilidade ou proibição de valoração, devendo ser ela devida e motivadamente valorada na sentença.

Vale ressaltar, contudo, que ainda no escopo desta segunda corrente de pensamento, são feitas algumas ressalvas no que toca à digital evidence. Segundo Gustavo Badaró, a desmaterialização e a facilidade de mutação dos elementos de prova digital justificariam a adoção de uma solução diversa, vez que se os métodos adotados na obtenção e produção desses elementos não forem fiáveis, eles não gozarão de qualquer potencial epistêmico, não possuindo aptidão para comprovar qualquer fato. Para o autor, "num sistema que respeite a presunção de inocência, não se poderá exigir do acusado a demonstração do prejuízo pela não

\footnotetext{
118 BADARÓ, Gustavo. Processo penal..., p. 514.

119 Vide nota 110.
} 
utilização das melhores práticas segundo a computer forensics, devendo a prova ser destituída de valor probatório" ${ }^{120}$.

De fato, no caso da produção de provas digitais por parte da Acusação, não nos parece ser adequado impor ao Acusado o ônus de demonstrar a violação ou inexistência de documentação da cadeia de custódia, bem como o prejuízo decorrente da não adoção das melhores técnicas na coleta, exame e análise desses elementos ou na elaboração do relatório. Contudo, remanesce nosso questionamento principal, relativo às hipóteses de produção de provas pela própria defesa, com vícios de rastreabilidade.

Para esses casos, é interessante observar que no âmbito da primeira corrente doutrinária mencionada anteriormente, qual seja, a que se posiciona no sentido de que a quebra da cadeia de custódia ensejaria a ilegalidade e consequente inadmissibilidade e desentranhamento da prova, encontramos posicionamentos que se inclinam pela admissão e valoração destes elementos probatórios quando em favor dos interesses da defesa.

Neste sentido, conforme explica Geraldo Prado, ainda que a disciplina constitucional brasileira nesta matéria não viabilize entendimentos como o de que toda prova ilícita pro reo seria admissível - tornando a exceção em regra - ou o de um juízo de proporcionalidade ${ }^{121}$ para aferir a possibilidade ou não, do emprego da prova ilícita em desfavor de alguém, isso não significa uma proibição de controle da antijuridicidade quando haja um conflito de interesses ${ }^{122}$.

$\mathrm{O}$ autor nos relembra que em sendo o processo penal constitucional uma garantia do imputado contra o arbítrio estatal, não há uma

${ }^{120}$ BADARÓ, Gustavo Henrique. Os standards metodológicos de produção na prova digital e a importância da cadeia de custódia. Boletim IBCCRIM, ano 29, n. 343, p. 7-9, jun./2021. p. 9.

${ }^{121}$ Exemplificativamente, no sistema alemão: WOLTER, Jürgen. O inviolável e o intocável no direito processual penal: reflexões sobre dignidade humana, proibições de prova, proteção de dados (e separação informacional de poderes) diante da persecução penal. Organização, introdução e tradução de Luís Greco. São Paulo: Marcial Pons, 2018. p. 132 e ss.

${ }^{122}$ PRADO, Geraldo. Breves notas sobre o fundamento constitucional da cadeia de custódia da prova digital. Revista Consultor Jurídico, 26 de janeiro de 2021. Disponível em: <https://www.conjur.com.br/2021-jan-26/prado-notas-cadeia-custodia-prova-digital>. Acesso em 21 de março de 2021. p. 25. 
posição de perfeita simetria entre este e o Estado investigador e acusador, de maneira com que, em havendo um conflito entre interesses constitucionalmente tutelados, será imprescindível, no caso concreto, a intervenção jurisdicional para aferir a excepcional possibilidade de admissão da prova em favor da comprovação da inocência e da liberdade do Acusado ${ }^{123}$.

Assim, em definitivo, haveria uma excepcional não-correspondência entre a proibição de ingresso e a proibição de valoração da prova, podendo ela ser eventualmente valorada, mas com emprego único e exclusivo em favor da defesa ${ }^{124}$ e nunca em desfavor de outrem ${ }^{125}$.

Os reflexos deste entendimento nas conclusões às quais podemos chegar quanto à cadeia de custódia, são os de que ainda que seja imprescindível a sua preservação a partir do momento de sua apreensão ou apresentação a órgão oficial, a prova poderá ser apresentada por terceiros, estando sujeita, é claro, a uma valoração de sua fiabilidade em caso de quebra da cadeia, ou seja, sujeita a uma "prova sobre a prova" ${ }^{126}$.

Diante de todo o exposto, não poderíamos chegar a outra conclusão que não a de que a prova coletada no âmbito de uma investigação interna, que eventualmente possua um vício de rastreabilidade apto a configurar uma "quebra da cadeia de custódia", poderá ser admitida em um processo penal - ainda que em caráter excepcional - desde de que sua valoração seja feita única e exclusivamente em favor da defesa ${ }^{127}$ e nela

${ }^{123}$ Neste sentido, ilustra o autor: "Não se pode torturar ou matar para obter a prova da inocência. Outras infrações, no entanto, podem levar a violação de bem jurídico que deve ser moderadamente suportado pela vítima em favor da comprovação da inocência e da garantia da liberdade de outrem" (Ibidem, p. 25).

${ }^{124}$ Sobre a majoritária interpretação no sentido da admissibilidade das provas ilícitas quando favoráveis ao Réu, conferir com detalhes em: AVOLIO, Luiz Francisco Torquato. Provas ilícitas: interceptações telefônicas, ambientais e gravações clandestinas. 7.ed. rev., atual. e ampl. São Paulo: Thomson Reuters Brasil, 2019. Versão ebook. Não paginado. Capítulo 3. Seção 3.2.3. Sob uma perspectiva de direito comparado: ARMENTA DEU, Teresa. A prova ilícita: um estudo comparado. Tradução de Nereu José Giacomolli. São Paulo: Marcial Pons, 2014. p. 82-84.

${ }^{125}$ PRADO, Geraldo. Breves notas..., p. 26.

${ }^{126}$ Ibidem, p. 27.

127 Até mesmo em razão do que fora sustentado na nota n. 94. 
seja aferida a sua fiabilidade. Jamais poder-se-á admitir a sua valoração para fundamentar a condenação de alguém.

Duas questões ainda restam, porém, sem solução minimamente pacífica. A primeira delas diz respeito a quem incumbiria o ônus de comprovação da retidão da cadeia de custódia, problemática essa que é controversa também no caso das evidências derivadas das investigações estatais e muito mais o será, no caso das investigações internas. Por um lado, poder-se-ia aplicar um regime próximo ao das nulidades e incumbir àquele que alegou o vício, a tarefa de comprova-lo. Esta solução, contudo, parece-nos que inviabilizaria, em muitas hipóteses e em especial no plano das investigações internas, a demonstração concreta da violação, uma vez que, quem produzir a prova é que possuirá as melhores (se não as únicas) condições para demonstrar sua integralidade, podendo ser dele este ônus ${ }^{128}$. Ademais, não podemos nos abstrair de que estamos aqui, no plano de uma "prova sobre a prova", e não no da comprovação dos elementos típicos ${ }^{129}$. Assim, mesmo na hipótese de que essa incumbência recaia sobre a defesa, que promovera a investigação da qual decorrera a prova viciada, não nos parece que esta solução afronte as suas garantias processuais. É certo, porém, que esta questão impõe maiores discussões.

Outro ponto controvertido é o do standard probatório necessário para demonstrar a "quebra" da cadeia de custódia - ou sua "integralidade”, no caso de atribuição do ônus à parte que a produziu. Conforme

${ }^{128}$ Neste sentido: BADARÓ, Gustavo Henrique. Processo penal..., p. 513-514.

${ }^{129}$ Esta consideração é muito importante pois, conforme expusemos em outra oportunidade, a eventual consideração da existência e eficácia dos programas de compliance na aferição da responsabilidade penal das pessoas jurídicas imporia à Acusação o ônus da dificultosa prova destes fatores, independentemente de se estes sejam aferidos no plano do injusto, da culpabilidade ou das causas de isenção de pena. Cfr.: JANUÁRIO, Túlio Felippe Xavier. O ônus da prova da existência e eficácia dos programas de compliance no âmbito do processo penal das pessoas jurídicas: um estudo com base no ordenamento jurídico espanhol. Revista Brasileira de Ciências Criminais, São Paulo, v. 27, n. 160, p. 219-257, out./2019. p. 239 e ss. A questão aqui certamente é diversa, pois se trata não da comprovação do compliance para fins de responsabilização penal (onde haveria primazia do in dubio pro reo), mas sim, da integralidade e autenticidade da prova, a qual seria muito mais factível por quem a produziu. 
explica Badaró, a doutrina norte-americana vai no sentido de não ser necessário o afastamento de toda e qualquer possibilidade de alteração ou substituição, mas tão somente, a demonstração do que for suficiente para que julgador possa crer que a prova é aquilo que sobre ela é afirmado. Nos casos em que a cadeia não for "facilmente identificável" ou for muito vulnerável à alteração, exige-se um grau maior de demonstração, a um patamar de ao menos uma probabilidade razoável de sua integralidade $^{130}$. Se por um lado, observa-se de pronto que estes critérios são extremamente vagos e abrem grande margem para discricionariedade, por outro, diante do silêncio legislativo e doutrinário a respeito desta questão nos sistemas de civil law, estes critérios podem ser tomados como ponto de partida para as futuras e necessárias discussões sobre este controvertido aspecto.

\section{Conclusão}

Conforme restou demonstrado ao longo do presente trabalho, os programas de compliance são desenvolvidos como uma potencial resposta às dificuldades estatais de regulação e fiscalização das atividades empresariais, bem como de detecção, prevenção e repressão de ilícitos cometidos nesta seara complexa e bem estruturada. Neste escopo, ainda que não imperiosamente vinculados com estes mecanismos, os procedimentos de investigação interna exercem uma importante função reativa no cerne corporativo, visando, mediante a condução de diversas diligências, a apuração de fatos potencialmente ilícitos ou contrários às suas normativas internas e que possam ensejar prejuízos econômicos e reputacionais, bem como responsabilizações das pessoas coletivas e singulares implicadas.

Observamos, contudo, que essa tendente "privatização das investigações" levanta inegáveis questionamentos, especialmente se considerado o eventual aproveitamento em processo penal, dos elementos colhidos nessas diligências. No estudo em apreço, analisamos especificamente uma destas problemáticas, qual seja, a da cadeia de custódia das provas

${ }^{130}$ Neste sentido, com múltiplas citações: BADARÓ, Gustavo Henrique. A cadeia de custódia..., p. 533-534. 
advindas de investigações internas e as possíveis consequências processuais penais de sua violação.

Importante instrumento para assegurar a rastreabilidade e, consequentemente, a fiabilidade e legalidade das provas apresentadas em juízo, pudemos constatar que o registro da cadeia de custódia da prova, ainda que sem expressa imposição legal para tanto, já é observada pela generalidade das entidades responsáveis pela condução de investigações internas, seja pelos benefícios processuais penais almejados pela empresa objeto da investigação - que a fazem se preocupar com a utilidade dos elementos colhidos nestas diligências, especialmente se ela estiver submetida ao regime da FCPA - seja pela própria preocupação com a reputação da empresa contratada e com a eficácia do programa de compliance da contratante.

O especialista terá, portanto, no curso das mais diversas diligências a serem empregadas, o dever de, não apenas empregar os competentes métodos científicos para a recolha, transporte e análise de cada um dos elementos colhidos, a fim de preservar sua integralidade e autenticidade, mas também de fazer constar do imperioso relatório, o registro da cada uma das etapas e da cronologia destes procedimentos, com as respectivas pessoas que neles interviram, viabilizando assim, o acesso e eventual impugnação de todas e cada uma das fases do processo empregado.

Eventual elipse nestes registros poderá acarretar em menor fiabilidade do elemento probatório, o que deverá ser considerado aquando de sua eventual apresentação em processo penal. Contudo, a despeito da ilegalidade ocorrida, ele poderá ser excepcionalmente admitido e valorado no processo penal, desde que única e exclusivamente em benefício da defesa do Acusado e de sua liberdade. Trata-se de uma solução que não apenas viabiliza ao juiz a análise da extensão dos concretos impactos da quebra da cadeia de custódia no caso concreto, como ainda impede que eventuais problemas de rastreabilidade em provas coletadas pelo Acusado, no cerne de suas investigações defensivas, impliquem em prejuízo para sua ampla defesa. 


\section{REFERÊNCIAS}

ANDRADE, Manuel da Costa. Sobre as proibições de prova no processo penal. Coimbra: Coimbra Editora, 1992.

ANTUNES, Maria João. Direito processual penal. Coimbra: Almedina, 2016.

ANTUNES, Maria João. Privatização das investigações e compliance criminal. Revista Portuguesa de Ciência Criminal, Coimbra, ano 28, n. 1, p. 119-128, jan./abr. 2018.

ANTUNES, Maria João. Processo penal e pessoa coletiva arguida. Coimbra: Almedina, 2020.

ARLEN, Jennifer; BUELL, Samuel W.. The Law of Corporate Investigations and the Global Expansion of Corporate Criminal Enforcement. University of Southern California Law Review, v. 93, n. 4, p. 697-762, set./2020. Disponível em: <https:// southerncalifornialawreview.com/2020/09/06/the-law-of-corporate-investigations-and-the-global-expansion-of-corporate-criminal-enforcement/>. Acesso em 21 de março de 2021.

ARMENTA DEU, Teresa. A prova ilícita: um estudo comparado. Tradução de Nereu José Giacomolli. São Paulo: Marcial Pons, 2014.

ÁVILA, Gustavo Noronha de; BORRI, Luiz Antonio. A cadeia de custódia da prova no "Projeto de Lei Anticrime": suas repercussões em um contexto de encarceramento em massa. Revista Direito Público, v. 16, n. 89, p. 114-132, set./out. 2019.

AVOLIO, Luiz Francisco Torquato. Provas ilícitas: interceptações telefônicas, ambientais e gravações clandestinas. 7. ed. rev., atual. e ampl. São Paulo: Thomson Reuters Brasil, 2019. Versão ebook.

AYRES, Ian; BRAITHWAITE, John. Responsive regulation: transcending the deregulation debate. Oxford: Oxford University Press, 1992.

BADARÓ, Gustavo Henrique. A cadeia de custódia e sua relevância para a prova penal. In: SIDI, Ricardo; LOPES, Anderson Bezerra (orgs.). Temas atuais da investigação preliminar no processo penal. 1. reimp. Belo Horizonte: Editora D’Plácido, 2018. p. 517-538.

BADARÓ, Gustavo Henrique. Epistemologia judiciária e prova penal. 2. tiragem. São Paulo: Thomson Reuters Brasil, 2019.

BADARÓ, Gustavo Henrique. Os standards metodológicos de produção na prova digital e a importância da cadeia de custódia. Boletim IBCCRIM, ano 29, n. 343, p. 7-9, jun./2021. 
BADARÓ, Gustavo Henrique. Processo penal. 8. ed. rev., atual. e ampl. São Paulo: Thomson Reuters Brasil, 2020.

BAER, Miriam H. When the Corporation Investigates Itself. In: ARLEN, Jennifer (ed.). Research Handbook on Corporate Crime and Financial Misdealing. Cheltenham, UK: Elgar, 2018. p. 308-333. https://doi.org/10.4337/9781783474479.00022

BALCARCE, Fabián I.; BERRUEZO, Rafael. Criminal compliance y personas jurídicas. Buenos Aires: Editorial B de F, 2016.

BARRILARI, Claudia Cristina. Crime empresarial, autorregulação e compliance. São Paulo: Thomson Reuters Brasil, 2018.

BAUMAN, Zygmunt. Globalização: as consequências humanas. Rio de Janeiro: Zahar, 1999.

BAYTELMAN A., Andrés; DUCE J., Mauricio. Litigación penal: juicio oral y prueba. 1. ed. Santiago: Ediciones Universidad Diego Portales, 2004.

BRAITHWAITE, John. Enforced self-regulation: a new strategy for corporate crime control. Michigan Law Review, v. 80, n. 7, p. 1466-1507, jun./1982. https:// doi.org/10.2307/1288556

CANESTRARO, Anna Carolina. As investigações internas no âmbito do criminal compliance e os direitos dos trabalhadores: considerações sobre a possibilidade de investigar e a transferência de informações para o processo penal. São Paulo: IBCCRIM, 2020.

CANESTRARO, Anna Carolina; JANUÁRIO, Túlio Felippe Xavier. Acordo de não persecução penal como instrumento de promoção de programas de compliance?. Boletim IBCCRIM, ano 29, n. 344, p. 23-25, jul./2021.

CANESTRARO, Anna Carolina. JANUÁRIO, Túlio Felippe Xavier. Dos níveis de exigibilidade dos procedimentos de investigação interna. In: INSTITUTO BRASILEIRO DE CIÊNCIAS CRIMINAIS. Anais do CPCRIM: IV Congresso de Pesquisas em Ciências Criminais, de 21 a 23 de outubro de 2020. São Paulo: IBCCRIM, 2020. p. 215-237. Disponível em: <https://www.ibccrim.org.br/publicacoes/pagina/3>. Acesso em 20 de março de 2021.

CANESTRARO, Anna Carolina; JANUÁRIO, Túlio Felippe X. Investigação defensiva corporativa: um estudo do Provimento 188/2018 e de sua eventual aplicação para as investigações internas de pessoas jurídicas. Revista Brasileira de Direito Processual Penal, Porto Alegre, v. 6, n. 1, p. 283-328, jan./abr. 2020. https://doi. org/10.22197/rbdpp.v6i1.324 
CANESTRARO, Anna Carolina; KASSADA, Daiane Ayumi; JANUÁRIO, Túlio Felippe Xavier. Nemo tenetur se detegere e programas de compliance: o direito de não produzir prova contra si próprio em face da Lei n. 13.303/16. In: SAAD-DINIZ, Eduardo et. al. (orgs.). Direito penal econômico nas ciências criminais. Belo Horizonte: Editora Vorto, 2019. p. 311-342.

CASEY, Eoghan. Foundations of digital forensics. In: CASEY, Eoghan (ed.). Digital Evidence and Computer Crime: forensic science, computers and the internet. 3. ed. Waltham, MA: Elsevier, 2011. p. 3-34.

COCA VILA, Ivó. ¿Programas de cumplimiento como forma de autorregulación regulada? In: SILVA SÁNCHEZ, Jesús-María (dir.); MONTANER FERNÁNDEZ, Raquel (coord.). Criminalidad de empresa y compliance: prevención y reacciones corporativas. Barcelona: Atelier, 2013. p. 43-76.

DEZEM, Guilherme Madeira. Curso de processo penal. 6.ed. São Paulo: Thomson Reuters Brasil, 2020. Versão ebook.

DEZEM, Guilherme Madeira; SOUZA, Luciano Anderson de. Comentários ao pacote anticrime: Lei 13.964/2019. São Paulo: Thomson Reuters Brasil, 2020.

DIAS, Gabriel Bulhões Nóbrega. A advocacia criminal, a investigação defensiva e a luta pela paridade de armas. Revista Brasileira de Ciências Criminais, São Paulo, v. 26 , n. 150 , p. $145-187$, dez./2018.

DIAS, Jorge de Figueiredo. Direito processual penal. 1. ed. reimp. Coimbra: Coimbra Editora, 2004.

EDINGER, Carlos. Cadeia de custódia, rastreabilidade probatória. Revista Brasileira de Ciências Criminais, São Paulo, v. 24, n. 120, p. 237-257, mai./jun. 2016.

ENGELHART, Marc. Sanktionierung von Unternehmen und Compliance: eine rechtsvergleichende Analyse des Straf- und Ordnungswidrigkeitenrechts in Deutschland und den USA. 2. ergänzte und erweiterte Auflage. Berlin: Dunker \& Humblot, 2012.

ENGELHART, Marc. The Nature and Basic Problems of Compliance Regimes. Freiburg im Breisgau: Max-Planck-Institut für ausländisches und internationales Strafrecht, 2018. https://doi.org/10.30709/archis-2018-3

FERNANDES, Fernando Andrade. O processo penal como instrumento de política criminal. Coimbra: Almedina, 2001.

FERRAJOLI, Luigi. Diritto e ragione: teoria del garantismo penale. Roma: Editori Laterza, 2004. 
FIDALGO, Sónia. A utilização da inteligência artificial no âmbito da prova digital direitos fundamentais (ainda mais) em perigo. In: RODRIGUES, Anabela Miranda. Inteligência artificial no direito penal. Coimbra: Almedina, 2020. p. 129-162.

FIGUEROA NAVARRO, María del Carmen. El aseguramiento de las pruebas y la cadena de custodia. La ley penal: revista de derecho penal, procesal y penitenciario, Madrid, v. 8, n. 84, p. 5-14, jul./ago. 2011.

FRIEDMAN, Howard M. The Insider Trading and Securities Fraud Enforcement Act of 1988. North Carolina Law Review, v. 68, n. 3, p. 465-494, 1990. Disponível em: <https://scholarship.law.unc.edu/nclr/vol68/iss3/2/>. Acesso em 18 de junho de 2020 .

GARCIA CAVERO, Percy. Criminal compliance. Lima: Palestra Editores, 2014.

GASCÓN INCHAUSTI, Fernando. Proceso penal y persona jurídica. Madrid: Marcial Pons, 2012.

GOMES FILHO, Antonio Magalhães. Direito à prova no processo penal. 1. ed. São Paulo: Revista dos Tribunais, 1997.

GOMES FILHO, Antonio Magalhães. Provas: Lei 11.690, de 09.06.2008. In: MOURA, Maria Thereza Rocha de Assis (coord.). As reformas no processo penal: as novas Leis de 2008 e os projetos de reforma. São Paulo: Editora Revista dos Tribunais, 2008. p. 246-297.

GÖSSEL, Karl Heinz. As proibições de prova no direito processual penal da República Federal da Alemanha. Revista Portuguesa de Ciência Criminal, Coimbra, v. 2, n. 3, p. 397-441, jul./set. 1992.

GÖSSEL, Karl Heinz. La prueba ilícita en el proceso penal. Revista de Derecho Penal, Buenos Aires, n. 1, p. 27-116, 2001.

GRINOVER, Ada Pellegrini; GOMES FILHO, Antonio Magalhães; FERNANDES, Antonio Scarance. As nulidades no processo penal. 12. ed. rev., e atual. São Paulo: Editora Revista dos Tribunais, 2011.

JANUÁRIO, Túlio Felippe Xavier. Criminal compliance e corrupção desportiva: um estudo com base nos ordenamentos jurídicos do Brasil e de Portugal. Rio de Janeiro: Lumen Juris, 2019.

JANUÁRIO, Túlio Felippe Xavier. O ônus da prova da existência e eficácia dos programas de compliance no âmbito do processo penal das pessoas jurídicas: um estudo com base no ordenamento jurídico espanhol. Revista Brasileira de Ciências Criminais, São Paulo, v. 27, n. 160, p. 219-257, out./2019. 
JANUÁRIO, Túlio Felippe Xavier. O sigilo profissional no âmbito das pessoas jurídicas: um estudo da particular posição dos in-house lawyers e dos advogados de compliance e de investigações internas. Revista Brasileira de Ciências Criminais, São Paulo, v. 27, n. 159, p. 297-339, set./2019.

LAUFER, William S.. Corporate Liability, Risk Shifting, and the Paradox of Compliance. Vanderbilt Law Review, v. 52, n. 5, p. 1343-1420, out./1999. Disponível em: <https://scholarship.law.vanderbilt.edu/vlr/vol52/iss5/9>. Acesso em 29 de junho de 2020 .

LENZE, Sebastian. Compliance, Internal Investigations und Beschuldigtenrechte: Mitarbeiterfragungen im Rahmen unternehmensinterner Ermittlungen und die strafprozessuale Verwertbarkeit selbstbelastender Aussagen unter besonderer Berücksichtigung der Korruptionsfälle Siemens und MAN. Frankfurt am Main: Peter Lang GmbH, 2014.

MARSHALL, Angus. Digital forensics: Digital Evidence in Digital Investigation. West Sussex, UK: Wiley-Blackwell, 2008.

MATIDA, Janaina. A cadeia de custódia é condição necessária para a redução dos riscos de condenações de inocentes. Boletim IBCCRIM, ano 28, n. 331, p. 6-9, jun./2020.

MENDES, Carlos Hélder Carvalho Furtado. Dado informático como prova penal confiável(?): apontamentos procedimentais sobre a cadeia de custódia digital. Revista Brasileira de Ciências Criminais, São Paulo, v. 27, n. 161, p. 131-161, nov. 2019.

MENEZES, Isabela A.; BORRI, Luiz A.; SOARES, Rafael J. A quebra da cadeia de custódia da prova e seus desdobramentos no processo penal brasileiro. Revista Brasileira de Direito Processual Penal, Porto Alegre, v. 4, n. 1, p. 277-300, jan./abr. 2018. https://doi.org/10.22197/rbdpp.v4i1.128

MIRANDA, Matheus de Alencar e. (In)eficiência de compliance e os direitos dos trabalhadores: evitando o "bode expiatório”. São Paulo: LiberArs, 2019.

MONTIEL, Juan Pablo. Sentido y alcance de las investigaciones internas en la empresa. Revista de Derecho de la Pontificia Universidad Católica de Valparaíso, v. XL, p. 251-277, 2013. https://doi.org/10.4067/s0718-68512013000100008

NATIONAL INSTITUTE OF STANDARDS AND TECHNOLOGY - NIST. Guide to Integrating Forensic Techniques into Incident Response: Recommendations of the National Institute of Standards and Technology. 2006. Disponível em: <https://csrc. nist.gov/publications/detail/sp/800-86/final>. Acesso em 27 de junho de 2020. 
NEIRA PENA, Ana María. La instrucción de los procesos penales frente a las personas jurídicas. Valencia: Tirant lo Blanch, 2017.

NESTLER, Nina. Internal Investigations: Definition und rechtstatsächliche Erkenntnisse zu interner Ermittlungen in Unternehmen. In: KNIERIM, Thomas C.; RÜBENSTAHL, Markus; TSAMBIKAKIS, Michael (Hrsg.). Internal Investigations: Ermittlungen im Unternehmen. 2. Neu bearbeitete Auflage. Heidelberg: C.F. Müller, 2016. p. 3-22.

NIETO MARTÍN, Adán. Compliance, criminologia e responsabilidade penal de pessoas jurídicas. In: NIETO MARTÍN, Adán; SAAD-DINIZ, Eduardo; GOMES, Rafael Mendes (coord.). Manual de cumprimento normativo e responsabilidade penal das pessoas jurídicas. 1. ed. Florianópolis: Tirant lo Blanch, 2018. p. 61-122.

NIETO MARTÍN, Adán. Investigações internas. In: NIETO MARTÍN, Adán; SAAD-DINIZ, Eduardo; GOMES, Rafael Mendes (coord.). Manual de cumprimento normativo e responsabilidade penal das pessoas jurídicas. 1. ed. Florianópolis: Tirant lo Blanch, 2018. p. 293-334.

NIETO MARTÍN, Adán. La responsabilidad penal de las personas jurídicas: un modelo legislativo. Madrid: Iustel, 2008.

NIETO MARTÍN, Adán. O cumprimento normativo. In: NIETO MARTÍN, Adán; SAAD-DINIZ, Eduardo; GOMES, Rafael Mendes (coord.). Manual de cumprimento normativo e responsabilidade penal das pessoas jurídicas. 1. ed. Florianópolis: Tirant lo Blanch, 2018. p. 29-60.

PAIS, Ana. Os programas de compliance e o risco de privatização do processo penal. Em especial, a problemática da "prova emprestada" e o princípio nemo tenetur se ipsum accusare. In: COSTA, José de Faria et. al. (coord.). Estudos em homenagem ao Prof. Doutor Manuel da Costa Andrade: Volume II: Direito Penal: Direito Processual Penal. Coimbra: Instituto Jurídico da Faculdade de Direito da Universidade de Coimbra, 2017. p. 663-686.

PIETH, Mark; IVORY, Radha. Emergence and convergence: corporate criminal liability principles in overview. In: PIETH, Mark; IVORY, Radha (ed.). Corporate criminal liability: emergence, convergence and risk. Rotterdam: Springer Netherlands, 2011. p. 3-62.

PRADO, Geraldo. A cadeia de custódia da prova no processo penal. São Paulo: Marcial Pons, 2019.

PRADO, Geraldo. Ainda sobre a "quebra da cadeia de custódia das provas”. Boletim IBCCRIM, ano 22, n. 262, p. 16-17, set./2014. 
PRADO, Geraldo. Breves notas sobre o fundamento constitucional da cadeia de custódia da prova digital. Revista Consultor Jurídico, 26 de janeiro de 2021. Disponível em: <https://www.conjur.com.br/2021-jan-26/prado-notas-cadeia-custodia-prova-digital>. Acesso em 21 de março de 2021.

RAMALHO, David da Silva. Métodos ocultos de investigação criminal em ambiente digital. Coimbra: Almedina, 2017. Versão ebook.

RODRIGUES, Anabela Miranda. Direito penal económico: uma política criminal na era compliance. Coimbra: Almedina, 2019.

ROXIN, Imme. Problemas e estratégias da consultoria de compliance em empresas. Revista Brasileira de Ciências Criminais, São Paulo, v. 23, n. 114, p. 321-339, mai./jun. 2015.

SAAD-DINIZ, Eduardo. Ética negocial e compliance: entre a educação executiva e a interpretação judicial. São Paulo: Thomson Reuters Brasil, 2019.

SAAD-DINIZ, Eduardo. Vitimologia corporativa. São Paulo: Tirant lo Blanch, 2019.

SCHARNBERG, Josephine. Illegale internal Investigations: strafrechtliche Grenzen unternehmensinterner Ermittlungen. Frankfurt am Main: Peter Lang GmbH, 2015.

SCHÜNEMANN, Bernd. Cuestiones básicas de dogmática jurídico-penal y de política criminal acerca de la criminalidad de empresa. Anuario de derecho penal $y$ ciencias penales, Madrid, v. 41, n. 2, p. 529-558, mai./ago. 1988.

SIEBER, Ulrich. Compliance-Programme im Unternehmensstrafrecht: ein neues Konzept zur Kontrolle von Wirtschaftskriminalität. In: SIEBER, Ulrich; DANNECKER, Gerhard; KINDHÄUSER, Urs; VOGEL, Joachim; WALTER, Tonio (Hrsg.). Strafrecht und Wirtschaftsstrafrecht-Dogmatik, Rechtsvergleich, Rechtstatsachen: Festschrift für Klaus Tiedemann zum 70. Geburtstag. Köln: Carl Heymanns Verlag, 2008.

SILVA SÁNCHEZ, Jesús-María. La expansión del derecho penal: aspectos de la política criminal en las sociedades postindustriales. 3. ed. ampl. Madrid: Edisofer S. L., 2011.

SOUSA, Susana Aires de. Questões fundamentais de direito penal da empresa. Coimbra: Almedina, 2019.

TARUFFO, Michele. La prueba de los hechos. Traducción de Jordi Ferrer Beltrán. 2. ed. Madrid: Editorial Trotta, 2005.

TARUFFO, Michele. La prueba. Traducción de Laura Manríquez y Jordi Ferrer Beltrán. Madrid: Marcial Pons, 2008. 
TONINI, Paolo; CONTI, Carlotta. Il diritto delle prove penali. Prima edizione aggiornata. Milano: Giuffrè Editore, 2012.

U.S. DEPARTMENT OF JUSTICE. OFFICE OF THE DEPUTY ATTORNEY GENERAL. Memorandum McNulty. Washington D.C., 2006. Disponível em: <https:// www.justice.gov/sites/default/files/dag/legacy/2007/07/05/mcnulty_memo. pdf $>$. Acesso em 23 de maio de 2020.

VALENTE, Manuel Monteiro Guedes. Cadeia de custódia da prova. 2. ed. Coimbra: Almedina, 2020.

VASCONCELLOS, Vinicius Gomes de. "The Right to Counsel and the Protection of Attorney-Client Privilege in Criminal Proceedings": direito de defesa técnica e relações cliente-advogado no processo penal contemporâneo. Revista Brasileira de Ciências Criminais, São Paulo, v. 29, n. 176, p. 257-272, fev./2021.

VIEIRA, Antonio. A cadeia de custódia da prova no processo penal: algumas notas sobre as alterações promovidas pela Lei 13.964/2019 (Pacote Anticrime). Trincheira Democrática: Boletim do Instituto Baiano de Direito Processual Penal, ano 3, n. 7, p. 27-32, fev./2020.

WOLTER, Jürgen. O inviolável e o intocável no direito processual penal: reflexões sobre dignidade humana, proibições de prova, proteção de dados (e separação informacional de poderes) diante da persecução penal. Organização, introdução e tradução de Luís Greco. São Paulo: Marcial Pons, 2018.

ZUÑIGA RODRÍGUEZ, Laura. Bases para un modelo de imputación de responsabilidad penal a las personas jurídicas. Navarra: Aranzadi, 2000. 


\section{Informações adicionais e declarações dos autores (integridade científica)}

Agradecimentos (acknowledgement): agradeço às Professoras Doutoras Maria João Antunes e Maria José Capelo, que, aquando da apresentação oral deste trabalho no âmbito da disciplina "A prova em Direito enquanto juízo e enquanto narrativa: perspectivas dogmáticas e metodológicas”, teceram considerações fundamentais para o seu aprimoramento. Agradeço também ao Professor Doutor Geraldo Prado, que gentilmente atendera aos meus questionamentos e me ajudara a refletir sobre alguns pontos essenciais para a versão final do artigo.

Declaração de conflito de interesses (conflict of interest declaration): o autor confirma que não há conflitos de interesse na realização das pesquisas expostas e na redação deste artigo.

Declaração de autoria e especificação das contribuições (declaration of authorship): todas e somente as pessoas que atendem os requisitos de autoria deste artigo estão listadas como autores; todos os coautores se responsabilizam integralmente por este trabalho em sua totalidade.

Declaração de ineditismo e originalidade (declaration of originality): o autor assegura que o texto aqui publicado não foi divulgado anteriormente em outro meio e que futura republicação somente se realizará com a indicação expressa da referência desta publicação original; também atesta que não há plágio de terceiros ou autoplágio. 
Dados do processo editorial

(http://www.ibraspp.com.br/revista/index.php/RBDPP/about/editorialPolicies)

- Recebido em: 25/09/2020

- Controle preliminar e verificação de plágio: 02/11/2020

- Avaliação 1: 05/11/2020

Equipe editorial envolvida

- Editor-chefe: 1 (VGV)

- Revisores: 3

- Avaliação 2: 11/11/2020

- Avaliação 3: 22/11/2020

- Decisão editorial preliminar 1 e deslocamento ao V7N2: 24/02/2021

- Retorno rodada de correções 1: 24/03/2021

- Decisão editorial preliminar 2: 01/06/2021

- Retorno rodada de correções 2: 27/06/2021

- Decisão editorial final: 28/06/2021

\section{COMO CITAR ESTE ARTIGO:}

JANUÁRIO, Túlio Felippe Xavier. Cadeia de custódia da prova e investigações internas empresariais: possibilidades, exigibilidade e consequências processuais penais de sua violação. Revista Brasileira de Direito Processual Penal, Porto Alegre, vol. 7, n. 2, p. 1453-1510, mai./ago. 2021. https://doi.org/10.22197/rbdpp.v7i2.453

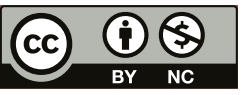

Esta obra está licenciada com uma Licença Creative Commons Atribuição-NãoComercial 4.0 Internacional. 